NBER WORKING PAPER SERIES

\title{
THE IMPACT OF COMPETITION ON MANAGEMENT QUALITY: EVIDENCE FROM PUBLIC HOSPITALS
}

\author{
Nicholas Bloom \\ Carol Propper \\ Stephan Seiler \\ John Van Reenen \\ Working Paper 16032 \\ http://www.nber.org/papers/w16032 \\ NATIONAL BUREAU OF ECONOMIC RESEARCH \\ 1050 Massachusetts Avenue \\ Cambridge, MA 02138 \\ May 2010
}

We would like to thank David Card, Caroline Hoxby, Robert Huckman, Dan Kessler, John McConnell, Ron Johnston, John McConnell, Luigi Pistaferri, Kathy Shaw, Carolyn Whitnall, and participants in seminars at the AEA, King's, LSE, NBER, Stanford, the Health and Econometrics and the RES Conferences, and the Department of Health for discussions. Our research partnership with Pedro Castro, John Dowdy, Stephen Dorgan and Ben Richardson has been invaluable. Financial support is from the HP/EDS Innovation Centre, the ESRC through the Centre for Economic Performance and CMPO and the National Science Foundation. The views expressed herein are those of the authors and do not necessarily reflect the views of the National Bureau of Economic Research.

NBER working papers are circulated for discussion and comment purposes. They have not been peerreviewed or been subject to the review by the NBER Board of Directors that accompanies official NBER publications.

(C) 2010 by Nicholas Bloom, Carol Propper, Stephan Seiler, and John Van Reenen. All rights reserved. Short sections of text, not to exceed two paragraphs, may be quoted without explicit permission provided that full credit, including $(\mathcal{O}$ notice, is given to the source. 
The Impact of Competition on Management Quality: Evidence from Public Hospitals

Nicholas Bloom, Carol Propper, Stephan Seiler, and John Van Reenen

NBER Working Paper No. 16032

May 2010

JEL No. F12,I18,J31,J45

\begin{abstract}
$\underline{\text { ABSTRACT }}$
In this paper we examine the causal impact of competition on management quality. We analyze the hospital sector where geographic proximity is a key determinant of competition, and English public hospitals where political competition can be used to construct instrumental variables for market structure. Since almost all major English hospitals are government run, closing hospitals in areas where the governing party has a small majority is rare due to fear of electoral punishment. We find that management quality - measured using a new survey tool - is strongly correlated with financial and clinical outcomes such as survival rates from emergency heart attack admissions (AMI). More importantly, we find that higher competition (as indicated by a greater number of neighboring hospitals) is positively correlated with increased management quality, and this relationship strengthens when we instrument the number of local hospitals with local political competition. Adding another rival hospital increases the index of management quality by one third of a standard deviation and leads to a $10.7 \%$ reduction in heart-attack mortality rates.
\end{abstract}

Nicholas Bloom

Stanford University

Department of Economics

579 Serra Mall

Stanford, CA 94305-6072

and NBER

nbloom@stanford.edu

Carol Propper

Department of Economics

University of Bristol

Bristol BS8 1TN

UK

carol.propper@bristol.ac.uk

\author{
Stephan Seiler \\ Houghton Street \\ London WC2A 2AE \\ United Kingdom \\ s.seiler@1se.ac.uk \\ John Van Reenen \\ Department of Economics \\ London School of Economics \\ Centre for Economic Performance \\ Houghton Street \\ London WC2A 2AE \\ United Kindom \\ and NBER \\ j.vanreenen@1se.ac.uk
}


In the US and almost every other nation, healthcare costs have been rapidly rising as a proportion of GDP (e.g. Hall and Jones, 2007). Since a large share of these costs are subsidized by the taxpayer, and this share could increase in the US under planned healthcare reforms, policy makers are highly focused on improving cost efficiency in hospitals. Given the large differences in hospital performance across a wide range of indicators (Kessler and McClellan, 2000; Propper and Van Reenen, 2010; Cutler, Huckman and Kolstad, 2009 and Skinner and Staiger, 2009) ${ }^{1}$, one route is through improving the management practices of hospitals.

Economists have long believed that competition is an effective way to improve management and therefore productivity. Adam Smith remarked "monopoly .... is a great enemy to good management" ${ }^{\text {2 }}$ Analyzing this relationship is hampered by two factors: first, the endogeneity of market structure and second, credibly measuring management. Identifying the causal effect of competition is challenging, but the fact that exit and entry are strongly influenced by politics in a publicly run healthcare system, like the UK National Health Service (NHS), offers a potential instrumental variable - the degree of political competition. Closing down a hospital is deeply unpopular and since the governing party is deemed to ultimately run the NHS, voters tend to punish this party at the next election if all or part of their local hospital closes down. A vivid example of this was in the 2001 General Election when a government minister was overthrown by a political independent, Dr. Richard Taylor, who campaigned on the single issue of "saving” the local Kidderminster Hospital (where he was a physician) which the government planned to scale down ${ }^{3}$.

Hospital opening and closures of public hospitals in England are centrally determined by the Department of Health. ${ }^{4}$ Since the mid 1990s there has been a concentration of services into a smaller number of public hospitals. ${ }^{5}$ If hospitals are less likely to be closed down in areas because these are

\footnotetext{
${ }^{1}$ This variation is not surprising - there is a huge variability in productivity in many other areas of the private and public sector (e.g. Foster, Haltiwanger and Syverson, 2008 and Syverson 2010).

${ }^{2}$ The Wealth of Nations, Book 1, Chapter XI Part 1, p.148

${ }^{3}$ See http://news.bbc.co.uk/1/hi/uk_politics/2177310.stm. There is other anecdotal evidence. For example, the Times from September 15th, 2006 reported that “A secret meeting has been held by ministers and Labour Party officials to work out ways of closing hospitals without jeopardising key marginal seats....”

${ }^{4}$ The vast majority of hospital care in the UK is provided in public hospitals. Private hospitals operate in niche markets, specialising in the provision of elective services for which there are long waiting lists in the NHS. Private financing of healthcare (including all out of pocket payments) accounts for only $16.7 \%$ percent of UK health care expenditure (Office for National Statistics, 2008).

${ }^{5}$ There are three sets of factors driving this consolidation. The first is the increasing demand for larger hospitals due to the benefits from increased volume within specialities and the grouping of multiple specialities together (Hensher and Edwards, 1999) ${ }^{5}$. This has also led to extensive hospital closures in the US (Gaynor, 2004). The second is the dramatic population growth in suburbs since World War II, far from the city centers where many hospitals were founded in the
} 
politically marginal districts (“constituencies”), there will be a larger number of hospitals in marginal areas than in areas where a party has a large majority. Similarly, new hospitals are more likely to be opened in marginal areas to obtain political goodwill. In either case, in equilibrium, politically marginal areas should benefit from a higher number of hospitals. Clear evidence for this can be seen from Figure 1 which plots out the number of hospitals per person in a political constituency against the winning margin of the governing party (the Labour Party in our sample period). When Labour's winning margin is small (under 5\%) there are about $10 \%$ more hospitals than when it or the opposition parties (Conservatives and Liberal Democrats) have a large majority.

Using the share of government-controlled (Labour) marginal political constituencies as an instrumental variable for hospital numbers we find a significant causal impact of greater local competition on hospital management practices. ${ }^{6}$ We are careful to condition on a wide range of confounding influences to ensure that our results are not driven by other factors (e.g. financial resources, different local demographics, the severity of patients treated at the hospital, etc.).

The second problem with examining the impact of competition on management is measuring managerial quality. In recent work we have developed a methodology for quantifying management practices (Bloom and Van Reenen, 2007; Bloom et al, 2009). The measures, covering incentives, monitoring, target-setting and lean operations were strongly correlated with firm performance. In this paper we apply the same basic methodology to measuring management in the healthcare sector. We implement our methods in interviews across 100 English acute (short term general) public hospitals (known as hospital trusts) interviewing a mixture of 161 clinicians and managers in two specialities: cardiology and orthopaedics. We cover $61 \%$ of all NHS providers of acute care in England.

We first show that our management practice scores are correlated with lower mortality rates from $\mathrm{AMI}^{7}$ and other surgical procedures, shorter waiting lists and better financial performance. While not causal, this suggests that the management measure has informational content. We then examine the causal impact of competition on management quality and health outcomes using our political

$19^{\text {th }}$ and early $20^{\text {th }}$ century. The third is the desire of policy makers to shift services from the hospital sector into the primary care setting.

${ }^{6}$ Each constituency returns a single member of parliament (MP) to the British House of Commons under a first past the post system. The party with a majority of MPs forms the government headed by the Prime Minister.

${ }^{7}$ Acute myocardial infarction, commonly known as a "heart attack". 
instrumental variables. We show that adding another rival hospital increases the index of management quality by one third of a standard deviation and leads to a $10.7 \%$ reduction in heartattack mortality rates.

Our identification strategy fits into the growing literature on the effect of the political environment on economic outcomes. One strand of the literature compares the incentives of politicians under different political rules. In a majoritarian system, such as the British one, politicians will pay greater attention to areas where there is more uncertainty about the electoral outcome, attempting to capture undecided voters in such "swing states" by devoting greater effort to these states. ${ }^{8}$ In our paper, we exploit political concern over one particular policy, healthcare provision. List and Sturm (2006) also look at a single issue - in their case, environmental policy at state level in the US - and show that when election outcomes are more uncertain politicians use this policy tool to attract undecided voters.

Our paper also relates closely to the literature on competition in healthcare. Policy makers in many countries have experimented with various ways of increasing effective competition in healthcare to increase productivity. In England, reforms to the healthcare system have introduced more competition between hospitals (Gaynor et al, 2010). There is extensive publicly available information and patients can choose the hospital they wish to receive treatment from. There is no consensus in the literature, however, on the effects of competition on hospital performance, so our paper contributes to a more positive assessment of the role of competitive forces (as in Kessler and McClellan, 2000, for the US or Gaynor et al, 2010, and Cooper et al, 2010, for England). ${ }^{9}$ Finally, our paper is linked to the literature on productivity and competition more broadly including papers by Nickell (1996), Syverson (2004), Schmitz (2005), and Fabrizio, Rose and Wolfram (2007).

\footnotetext{
${ }^{8}$ Theoretical models showing this include Lindbeck and Weibull (1987), Persson and Tabellini (1999), Lizzeri and Persico (2001) and Miles-Ferretti et al. (2002). The latter three papers compare majoritarian with proportional elections and find that they lead to different size and compositions of public expenditure (which is due to different groups being targeted). Empirical evidence to support this includes Persson and Tabellini (1999) and Miles-Ferretti et al. (2002). Nagler and Leighley (1992) and Stromberg (2008) establish empirically that candidates allocate relatively more of their election campaign resources to swing states. Clark and Milcent (2008) show the importance of political competition in France for healthcare employment.

${ }^{9}$ For example, Dranove and Satherthwaite (2000) or Gaynor and Haas-Wilson (1999).
} 
The structure of the paper is as follows. The next section discusses the data, Section II describes the relationship between hospital performance and management quality, Section III analyzes the effect of competition on hospital management and Section IV concludes.

\section{DATA}

The data used for the analysis is drawn from several sources. The first is the management survey conducted by the Centre for Economic Performance (CEP) at the London School of Economics, which includes 18 questions from which the overall management score is computed plus additional information about the process of the interview and features of the hospitals. This is complemented by external data from the UK Department of Health and other health regulators, which provides information on measures of quality and access to treatment as well as hospital characteristics such as patient intake and resources. Finally we use data on election outcomes at the constituency level from the British Election Study. The descriptive statistics for all the relevant variables that are used in our analysis are in Table 1.

\section{I.A. Management Survey Data}

The core of this dataset is made up of 18 questions which can be grouped in the following four subcategories: operations (3 questions), monitoring (3 questions), targets (5 questions) and incentives management (7 questions). For each one of the questions the interviewer reports a score between 1 and 5, a higher score indicating a better performance in the particular category. A detailed description of the individual questions and the scoring method is provided in Appendix A. ${ }^{10}$

To try to obtain unbiased responses we use a double-blind survey methodology. The first part of this was that the interview was conducted by telephone without telling the respondents in advance that they were being scored. This enabled scoring to be based on the interviewer's evaluation of the hospital's actual practices, rather than their aspirations, the respondent's perceptions or the interviewer's impressions. To run this "blind” scoring we used open questions (i.e. "can you tell me how you promote your employees”), rather than closed questions (i.e. “do you promote your employees on tenure [yes/no]?”). Furthermore, these questions target actual practices and examples, with the discussion continuing until the interviewer can make an accurate assessment of the

10 The questions in appendix A correspond in the following way to these categories. Operations: questions 1-3, Monitoring: questions 4-6, Targets: questions 8-12, Incentives management: questions 7 and 13-18. 
hospital's typical practices based on these examples. For each practice, the first question is broad with detailed follow-up questions to fine-tune the scoring. For example, in dimension (1) Layout of patient flow the initial question is "Can you briefly describe the patient journey or flow for a typical episode?” is followed up by questions like “How closely located are wards, theatres and diagnostics centres?”

The second part of the double-blind scoring methodology was that the interviewers were not told anything about the hospital's performance in advance of the interview. The interviewers were specially trained graduate students from top European and U.S. business schools. Since each interviewer also ran 46 interviews on average we can also remove interviewer fixed effects in the regression analysis.

Obtaining interviews with managers was facilitated by a supporting letter from the Department of Health, and the name of the London School of Economics, which is well known in the UK as an independent research university. We interviewed respondents for an average of just under an hour. We approached up to four individuals in every hospital - a manager and physician in the cardiology service and a manager and physician in the orthopaedic service (note that some managers may have a clinical background). There were 164 acute hospital trusts with orthopaedics or cardiology departments in England when the survey was conducted in 2006 and 61\% of hospitals (100) responded. We obtained 161 interviews, 79\% of which were with managers (it was harder to obtain interviews with physicians) and about half in each speciality. Furthermore, the response probability was uncorrelated with observables such as performance outcomes and other hospital characteristics (see Appendix B). ${ }^{11}$

Finally, we also collected a set of variables that describe the process of the interview, which can be used as "noise controls" in the econometric analysis. These included interviewer fixed effects, the position of the interviewee (clinician or manager), and his/her tenure in the post. Including these controls helps reduce residual variation.

\footnotetext{
${ }^{11}$ In the sixteen bivariate regressions of sample response we ran only one was significant at the $10 \%$ level (expenditure per patient).
} 


\section{I.B. Hospital Competition and Political Competition}

Since there are costs from treating patients far from where they live, healthcare competition always has a strong geographical element. Our main competition measure is simply the number of other public hospitals within a given "catchment area” for each hospital. We show experiments with a Herfindahl index as well which takes activity in the hospital into account, but the market shares are more likely to be endogenous (Kessler and McClellan, 2000), so our baseline estimates use the simpler measure. Our baseline results use a 30km radius (about one hour's drive) around the hospital, but we also report robust results when using wider market definitions such as $20 \mathrm{~km}$ or $40 \mathrm{~km}$ radius instead. ${ }^{12}$

We use data on outcomes of the national elections at the constituency level from the British Election Study. We observe the vote shares for all parties and use these to compute the winning margin. We define a constituency to be marginal if the winning margin is below $5 \%$ (we also show robustness to other thresholds such as $3 \%$ or $7 \%$ ). As hospitals usually have a catchment area that comprises several constituencies we use the share of marginal constituencies in a $30 \mathrm{~km}$ radius of the hospital as our main measure of political competition to match the hospital competition measures.

Note that the typical hospital in the UK treats about 72,000 patients a year while the typical political constituency has about 70,000 voters. So the closure of a hospital in a marginal constituency by the Government has an important effect on potential voters, increasing the likelihood of the Government losing that constituency in the next election. In other constituencies where the Government has a large lead over (or lag far behind) opposition parties there are lower incentives to avoid hospital closures, as changes of a few percentage points in voting will not alter parliamentary outcomes given the "first past the post" electoral system. ${ }^{13}$ We exploit this combination of public hospitals and central controlled hospital closures to generate a quasi-experiment for the number of hospitals.

There are three main parties in the UK (Labour, Conservative and Liberal Democrat). We distinguish between marginal constituencies which are controlled by the governing party (Labour) and Opposition parties. We test and confirm that the strongest effects are in the Labour controlled

\footnotetext{
${ }^{12}$ We use the number of public hospitals, as private hospitals generally offer a very limited range of services (e.g. they do not have Emergency Rooms).

${ }^{13}$ Britain's "first past the post" system means that the party with the highest vote share in each constituency wins that constituency. In a proportional representation political system this incentive to keep hospitals open in marginal constituencies does not operate as Governments care about total votes.
} 
marginal seats. ${ }^{14}$ Our key instrumental variable is therefore the lagged share of Labour marginal constituencies defined as constituencies where Labour won, but by less than $5 \%$. We use Labour marginals in 1997 since seats which were marginal in the 1997 election were typically perceived as marginal from the mid-1990s until after the early $2000 \mathrm{~s}^{15}$, which was a key period of extensive hospital consolidation.

In some regressions we also condition on a flexible polynomial in the Labour vote share and identity of the winning party as this could reflect some unobservables correlated with health status in the hospital catchment area (and therefore the number of hospitals).

\section{I.C. Hospital Performance Data}

Productivity is difficult to measure in hospitals, so regulators and researchers typically use a wide range of measures ${ }^{16}$. The clinical outcomes we use are the mortality rates following emergency admissions for (i) AMI and (ii) surgery. ${ }^{17}$ We choose these for four reasons. First, regulators in both the USA and the UK use selected death rates as part of a broader set of measures of hospital quality. Second, using emergency admissions helps to reduce selection bias because elective (nonemergency) cases may be non-randomly sorted towards hospitals. Third, death rates are well recorded and cannot be easily "gamed" by administrators trying to hit targets. Fourth, the volume of emergency admissions for heart attacks and surgery are relatively high, so reducing the noise in the death rates.

\footnotetext{
${ }^{14}$ There are two reasons for this. First, Labour was the party in power so hospital closures were politically more associated with their Members of Parliament. Second, the period we examine was Prime Minister Blair's honeymoon period in power during which Labour's popularity was at an all time high, so its marginals were more at risk than opposition marginals as Labour's vote share trended downwards as its early popularity eroded.

${ }^{15}$ The reason is Labour's victory in 1997 was forecast from the mid-1990s onwards and their polling margin from 1997 was relatively constant until the early 2000s.The Conservatives won a narrow (21 seat) victory in 1992, but became increasingly unpopular from the mid 1990s onwards, particularly after the election of Tony Blair as leader of the Labour party in 1994. So by 1995 Labour was far ahead of the Conservatives in the polls and maintained this lead into the 1997 General Election. In the 2001 election Labour had a very similar margin of victory (167 seats) as the 1997 election (179 seats). They still won the 2005 election but with a reduced margin (66 seats), with their popularity declining slowly between 2001 and 2005 (Crewe, 2005). There is a high correlation between the share of marginal Labour constituencies in 1997 and 2001 (0.73).

${ }^{16}$ See for example http://2008ratings.cqc.org.uk/findcareservices/informationabouthealthcareservices.cfm

${ }^{17}$ Examples of the use of AMI death rates to proxy hospital quality include Kessler and McClellan (2000), Gaynor (2004) and, for the UK, Propper et al (2008). Death rates following emergency admission were used by the English healthcare quality regulator in 2001/2. The AMI mortality rate is for all deaths within 28 days of admission, the emergency surgery mortality rate is for all deaths within 30 days of admission.

http://www.performance.doh.gov.uk/performanceratings/2002/tech_index trusts.html
} 
As a measure of access to care we use the size of the waiting list for all operations (long waits have been an endemic problem of the UK NHS and of considerable concern to the general public, Propper et al, 2010). As another quality marker we use MRSA infection rates, used as a measure of hospital hygiene. ${ }^{18}$ We use the hospitals’ operating margin as a measure for their financial efficiency and the average intention of staff intending to leave in the next year as an indication of worker job satisfaction. All of these measures have been used by the UK government to rate NHS hospitals in England. Finally, we use the UK Government's Health Care Commission (HCC) ratings which represent a composite performance measure across a wide number of indicators. The HCC rates hospitals along two dimensions of "resource use” and "quality of service” (measured on a scale from 1 to 4$).^{19}$

\section{I.D. Other Controls}

First, we control for patient case-mix by including the age/gender profile of total admissions at the hospital level in all of the regressions. ${ }^{20}$ We also control for the total number of admissions to allow for the fact that better hospitals may attract more patients and raise their quality if there are economies of scope or scale. Second, we control for the health of the population in the hospital's catchment area by using the within-gender age distribution (22 groups) and the overall mortality rate. We also control for population density. Third, we control for resources of the hospitals, which are all derived from general taxation. The (public) purchasers of health care cover a defined geographical area and are allocated resources on the basis of a formula that measures need for healthcare (essentially, the demographics of the area the hospital is located in). The purchasers use these resources to buy healthcare from hospitals, at fixed national prices, for their local population. Purchasers do not own hospitals nor are vertically integrated with hospitals. This system is intended to ensure resources are neither used to prop up poorly performing local hospitals nor are subject to local political influence. However, we are concerned to ensure that we control for the impact of resources as they may affect both performance and quality of management and to ensure that our instrumental variables results are not driven by resources that may be associated with political

\footnotetext{
${ }^{18}$ MRSA is Methicillin-Resistant Staphylococcus Aureus.

${ }^{19}$ We use the 2006 values as these are coincident with the timing of the survey and average across the two measures. We also report experiments where we disaggregate the index and construct our own (re-aggregated) index. See Appendix B for more details on the construction of this Pseudo-HCC index.

${ }^{20}$ Specifically we have 11 age categories for each gender $(0-15,16-45,46-50,51-55,56-60,61-65,66-70,71-75,76-80$, 81-85, >85). Admission proportions are specific to the condition in the case of AMI and general surgery. For all other performance indicators we use the same variables at the hospital level. Propper and Van Reenen (2010) show that in the English context the age-gender profile of patients does a good job of controlling for case-mix.
} 
marginality. We therefore considered a large set of measures of the quantity and quality of resources including whether hospitals have been given greater autonomy from central control (known as "Foundation Trusts”), the number of sites, the age building (a proxy for capital quality) and expenditure per patient as a direct measure of funding. ${ }^{21}$

\section{I.E. Preliminary Data Analysis}

The management questions are all highly correlated (see Bloom and Van Reenen, 2007) so we will usually aggregate the questions together either by taking the simple average (as in the figures) or by z-scoring each individual question and then taking the z-score of the average across all questions (in the regressions). ${ }^{22}$

Figure 2 divides the HCC score into quintiles and shows the average management score in each bin. There is a clear upward sloping relationship with hospitals that have higher management scores also enjoying higher HCC rankings. Figure 3 plots the entire distribution of management scores for our respondents (in the upper Panel A). There is a large variance with some well managed firms, and other very poorly managed. In Panel B we present a comparison between hospitals and UK manufacturing firms. ${ }^{23}$ Hospitals clearly have lower management scores than manufacturing firms, particularly for incentives management as they have weaker links between performance and pay, promotion, hiring and firing.

\section{HOSPITAL PERFORMANCE AND MANAGEMENT PRACTICES}

Before examining the impact of competition on management practices we undertake two types of data validation test. The first involves running a second independent interview, with a different MBA interviewer speaking to a different manager (or doctor) at the same hospital. We find that these independently run first and second interviews have a correlation in their average management

\footnotetext{
${ }^{21}$ We also tried to include further control variables (results are not reported): a dummy for whether a hospital is a teaching or a specialist hospital, total hospital employment, the number of acute beds, the number of medical staff and doctor vacancy rates. The results are not sensitive to including these additional variables.

${ }^{22}$ Z-scores are measures normalized to have a mean of zero and a standard deviation of one. Factor analysis confirms that there is one dominant factor that loads heavily and positively on all questions. As with the earlier work, there is a second factor that loads positively on the incentives management questions, but negatively on the monitoring/operations questions. This suggests that there is some specialization across hospitals in different forms of management.

${ }^{23}$ To make the samples somewhat comparable we keep only establishments who have between 50 and 5,000 employees and who are domestically owned (i.e. we drop multinationals from the manufacturing sample). Furthermore, in both panels we are using the average management score from only 16 comparable questions, because two questions on lean manufacturing are difficult to compare across sectors (questions 1 and 2 in Appendix A)
} 
scores across the 18 questions of 0.530 (p-value 0.001), as plotted in Appendix Figure A1. While this correlation is less than unity, implying some variation in management practices across managers and/or measurement error in the survey instrument, it is also significantly greater than zero suggesting our survey is picking up consistent differences in practices across hospitals.

The second type of data validation test is to investigate if the management score is robustly correlated with external performance measures. This is not supposed to imply any kind of causality. Instead, it serves as another data validation check to see whether a higher management score is correlated with a better performance.

We estimate regressions of the form:

$$
y_{i}^{k}=\alpha M_{i j}+\beta^{\prime} x_{i j}+u_{i j}
$$

where $y_{i}^{k}$ is performance outcome $k$ (e.g. AMI mortality) in hospital $i, M_{i j}$ is the average management score of respondent $j$ in hospital $i, x_{i j}$ is a vector of controls and $u_{i j}$ the error term. Since errors are correlated across respondents within hospitals we cluster our standard errors at the hospital level. ${ }^{24}$ We present some results disaggregating the 18 questions, but our standard results simply z-score each individual question, average these into a composite and then z-score this average. We use 2005/6 average outcomes to coincide with the date of the management survey.

Table 2 shows results for regressions of each of the performance measured on the standardized management score. The management score in the top row (A) is calculated over the 18 survey questions. The other rows show results based on the four different categories of questions. Looking across the first row higher management scores are associated with better hospital outcomes across all the measures and this relationship is significant in every case. This immediately suggests our measure of management has informational content.

Looking in more detail, in the first column of Table 2 we present the AMI mortality rate regressed on the management score controlling for a wide number of confounding influences. ${ }^{25}$ High

\footnotetext{
${ }^{24}$ We weight the observations with the inverse of the number of interviews conducted at each hospital. This gives equal weight to each hospital in the regressions.

${ }^{25}$ As is standard we drop observations where the number of cases admitted for AMI is low because this leads to large swings in observed mortality rates. Following Propper and Van Reenen (2010) we drop hospitals with under 150 cases of AMI per year, but the results are not sensitive to the exact threshold used.
} 
management scores are associated with significantly lower mortality rates from AMI - a one standard deviation increase in the management score is associated with a reduction of 0.66 percentage points in the rate of AMI mortality (or a fall in 4\% over the mean AMI mortality of 17.1). Since there are 37,000 emergency AMI admissions in aggregate this corresponds to 246 fewer deaths a year. Column (2) examines death rates from all emergency surgery and again shows a significant correlation with management quality. ${ }^{26}$ Column (3) shows better managed hospitals tend to have significantly lower waiting lists and significantly lower MRSA infection rates (column (4)). The financial performance measured by the hospital's operating margin is higher when hospitals have higher management scores (column (5)). ${ }^{27}$ Column (6) indicates that higher management scores are also associated with job satisfaction (a lower probability of the average employee wanting to leave the hospital). In the final two columns we use composite measures from the HCC and compute a "pseudo HCC rating" by attempting to reverse engineer the process by which the original rating was calculated (see Appendix B). The management practice score is significantly and positively correlated with both of these measures.

The lower panel of Table 2 repeats the exercise using the different categories of management practice questions, where each row is an individual regression. The results are very similar although the coefficients are less precisely estimated. ${ }^{28}$ Different categories are more strongly correlated with different performance measures in an intuitive way. For example "Lean Operations" has the most explanatory power for MRSA infection rates and a higher "Incentives Management" score significantly lowers the staff's intention to leave the job.

Overall, Table 2 indicates that our measure of management practices is positively associated with superior hospital outcomes across a wide range of performance indicators. ${ }^{29}$

\footnotetext{
${ }^{26}$ We exclude two specialist hospitals from this regression as they are difficult to compare to the rest in terms of all emergency admissions.

${ }^{27}$ The operating margin is influenced by both revenue and costs per spell. As the revenue side is fixed (hospitals receive a fixed national payment per type of case, known as Payment by Results and similar to the US fixed payment per DRG system), the operating margin is effectively a measure of costs.

${ }^{28}$ This suggests that averaging over different questions helps to reduce noise. We also examined decomposing the management score even further. When regressing the scores for individual questions on the HCC rating, 7 out of 18 questions are significant at the $5 \%$ level and of these only one is significant at the $1 \%$ level).

${ }^{29}$ Our results are also consistent with McConnell et al. (2009) who use the Bloom and Van Reenen (2007) methodology to collect management data on 147 US addiction treatment programs, finding a positive management performance relationship.
} 


\section{MANAGEMENT PRACTICES AND HOSPITAL COMPETITION}

\section{III.A Basic Results}

To investigate whether competition improves management practices, column (1) of Table 3 presents an OLS regression of management quality on the number of rivals in a hospital's geographical catchment area. There is a positive and significant coefficient on this competition measure: adding one rival hospital is associated with an increase in management quality of 0.12 of a standard deviation.

To address the endogeneity concern we use the political instrumental variable described above - the degree to which a hospital is located in a politically marginal area held by the governing Labour party. Column (2) reports the first stage indicating that the share of local Labour-controlled local marginal constituencies is highly significant in explaining increased total hospital numbers. Consistent with Figure 1, a one standard deviation increase in political marginality (0.109) leads to about 0.6 additional hospitals $(0.638=0.109 * 5.850)$. In Column $(3)$ we look at the IV results, and find a positive effect of the number of local hospitals on management quality that is significant at the $10 \%$ level. Adding an extra competitor increases the index of management quality by over one third of a standard deviation (0.361).

The specification in columns (1) through (3) contains only very basic controls (population density and age, four interviewer dummies and whether the hospital was a foundation trust), so a concern is that the relationship between management quality and competition is driven by omitted variables. In columns (4) to (6) we include a richer set of covariates including area mortality rates, the age and gender mix of hospital patients, linear terms in the share of Labour votes and the identity of the winning party and other variables as discussed in section $1 .^{30}$ The full set of results are in Table B3, but Table 3 shows that the coefficients on our key variables are little changed by these additional covariates and in fact the second stage coefficient in column (6) is 0.543 , slightly stronger than in column (3). An alternative measure of competition is to use the "numbers equivalent" of the

\footnotetext{
${ }^{30}$ The set of control variables used in this specification is identical to the ones used in Table 2, except for the additional controls for area demographics and population density.
} 
Herfindahl Index (HHI). ${ }^{31}$ Including this instead of the number of hospitals we obtain a coefficient (standard error) of $0.636(0.257)$ in the second stage, which is consistent with column (6). ${ }^{32}$

Column (7) shows an alternative first stage where we also include an extra variable indicating the proportion of marginal constituencies controlled by the opposition parties. Although the coefficient on this variable is positive, suggesting that these areas are also likely to have more hospitals, it is smaller and insignificant at conventional levels. This is consistent with our interpretation that marginals controlled by the governing party are the ones with most political saliency. If we use just marginality regardless of the controlling party, we obtain a coefficient of 2.369 with a standard error of 0.899 in the first stage. In any case, when we use both instruments from column (7) in the second stage the results are very similar to just using Labour marginals (see column (8)).

Finally, although our focus here is on the impact of competition on management quality, we could also consider the impact on more direct measures of hospital performance. We present OLS results in column (9) which indicates that hospitals facing more competition have significantly fewer deaths following emergency AMI admissions. ${ }^{33}$ Column (10) uses our IV strategy and indicates that there appears to be a causal effect whereby adding one extra hospital reduces death rates by 1.83 percentage points (or $10.7 \%$ over the average rate of 17.1).

\section{III.B Robustness}

As noted earlier, none of the qualitative results depend on the precise thresholds used for catchment area or definition of political marginal. Using a $40 \mathrm{~km}$ catchment area instead of the baseline $30 \mathrm{~km}$ shows slightly stronger results (a coefficient on competition of 0.849 with a standard error of 0.337). Using a 20km catchment area gives a coefficient (standard error) on competition of 0.548 (0.294) in IV. Using a 3\% (instead of 5\%) threshold for marginality reduced the coefficient (standard error) on competition to $0.321(0.158)$ in the IV estimates and increasing it to $7 \%$ magnified the coefficient

\footnotetext{
${ }^{31}$ The HHI is an inverse measure of competition which ranges from 0 (very competitive) to 1 (monopoly). The "numbers equivalent" measure is calculated as $1 / \mathrm{HHI}$. It can be interpreted as the number of equally sized firms that would lead to a particular value of the HHI.

${ }^{32}$ In the first stage we obtain a coefficient (standard error) on political marginality of 4.401 (1.203).

${ }^{33}$ Running the same OLS regressions but using each of the other seven performance outcomes in Table 2 as a dependent variable reveals that competition is associated with better performance in every case. However, competition is only significant for AMI mortality rates.
} 
(standard error) on competition to 1.068 (0.482). We also considered adding higher order controls for Labour's vote share or dropping Labour's vote share completely with robust results. ${ }^{34}$

Is it possible that marginality is associated with higher healthcare funding? As we noted above, funding for healthcare is allocated on the basis of need and is a separate and more transparent process than hospital exit and entry, so there is no automatic association between funding and marginality. However, it is possible that lobbying by a marginal politician could lead to greater funding. We therefore added controls for funding (expenditure per patient) into the regression. The coefficient for this variable is insignificant in both stages and does not alter the coefficient on competition. ${ }^{35}$ We also controlled for the age of the hospitals' buildings to test whether marginal constituencies received more resources in terms of newer capital equipment. In fact we find the contrary to be true: in marginal constituencies hospital buildings tend if anything to be older, presumably because hospital closures are rarer. ${ }^{36}$

Another possible confounding factor is capacity. Maybe when multiple hospitals operate in the same area this reduces the pressure on doctors so that they can improve management practices? One point to note is that weakening time pressure has ambiguous effects on management practices as it could lead managers to slack (Bloom and Van Reenen, 2010). We investigate this empirically by including capacity controls such as physicians per person in the hospital's catchment area and physicians per patient in the hospital itself and find the results are robust. ${ }^{37}$

Finally, a concern with the instrument might be that the lower risk of a hospital being closed down in marginal constituencies may decrease managerial effort because the Chief Executive is less afraid of losing his job (the "bankruptcy risk" model of Schmidt, 1997). This mechanism is unlikely to be

\footnotetext{
${ }^{34}$ Using a squared and a cubic term for Labour's vote share in addition to the linear one leads to a coefficient (standard error) on competition of 0.551 (0.208). Dropping the Labour vote share completely yields a coefficient of $0.534(0.220)$. We also run the first stage of our IV specification using the number of private hospitals as dependent variable. We find that marginality is insignificant in this case. This constitutes another piece of evidence that our marginality measure is not picking up unobserved area health status.

${ }^{35}$ The coefficient (standard error) on the number of hospitals is $0.498(0.211)$ and the first stage coefficient (standard error) on the marginality variable is 5.311 (1.438).

${ }^{36}$ Including building age, the coefficient (standard error) on the number of hospitals is $0.537(0.306)$ and the first stage coefficient on the marginality variable 4.817 (1.613).

${ }^{37}$ For example, adding full time equivalent physicians per person in the hospital's catchment area leads to a coefficient (standard error) on competition in of 0.849 (0.490) in column (6) and -2.146 (1.318) in column (10). The coefficient on physicians per person is insignificant and actually negative which suggests that lowering time pressure leads to managerial slack. Adding the number of physicians per patient in the hospital leads to a coefficient (standard error) in Table 3 of 0.502 (0.234) on competition in column (6) and -1.801 (1.034) in column (10).
} 
material in the NHS, however, because the Government almost always fires the Chief Executive in poorly performing hospitals rather than closing them down. In the context of our set-up, the bankruptcy risk model still implies that marginality would cause a greater number of hospitals, but this would be associated with a decrease in management quality. We find the opposite: managerial quality increases with the number of hospitals. Furthermore, looking at the reduced form, management quality is higher in areas where there is greater political competition, implying that the bankruptcy risk model is unlikely to matter much in our data. ${ }^{38}$

\section{III.C Discussion of magnitudes and mechanisms}

\section{Magnitudes}

Why is the IV estimate of competition so much larger than the OLS estimate? Some of this might be due to attenuation bias or have a LATE (Local Average Treatment effect) interpretation ${ }^{39}$. But, most obviously, the reverse causality problem is likely to bias OLS towards zero as hospitals in the neighbourhood of a well managed hospital are more likely to be closed down. The closure is economically and politically easier to justify if patients have a good substitute due to the presence of a neighboring high quality hospital. Because of this, a higher management score would generate a lower number of competing hospitals, just as in the standard case where a very efficient firm will tend to drive weaker firms from the market. This would lead OLS estimates to be biased towards zero as we observe in Table 3.

In terms of the magnitudes of the competition effect, the distribution of numbers of hospitals is very skewed (a standard deviation of 9.7 in Table 1). This is because of a bimodal pattern with a much greater density of hospitals in London (a mean of 30.7 and standard deviation of 2.1) than outside of London (a mean of 3.5 and standard deviation 3.8). ${ }^{40}$ So an increase of three hospitals is a more representative "standard deviation" experiment than an increase of ten hospitals. According to our

\footnotetext{
${ }^{38}$ There is a coefficient (standard error) on political marginality of 2.800 (1.162) in the reduced form regression with management as the dependent variable - see Table B3 column (2).

${ }^{39}$ The LATE interpretation is that the effect of competition is larger on the compliers than non-compliers. Since 1945 Britain has been a two party democracy with the Conservative party strong in the richer areas which because they were on average healthier had relatively fewer hospitals per person. If there are diminishing returns to competition we would expect a larger effect of adding hospitals in these "Conservative" areas. From the mid 1990s under Tony Blair, the Labour party made large inroads into these wealthier constituencies so in our sample period a typical Labour marginal was wealthier/healthier than the average Labour seat (in our data area mortality was $17 \%$ lower in the Labour marginals compared to the rest of the country). Thus, the group of areas induced to add an extra hospital by the instrumental variable (the compliers) are those likely to have a larger than average treatment effect on hospital performance, which is why the IV estimates could lie above the OLS estimates.

${ }^{40}$ The results are robust to dropping the 20 London hospitals. The instrument remains significant at the $5 \%$ level in the first stage and the coefficient (standard error) on competition is $0.756(0.369)$ in the second stage.
} 
estimates an increase of three hospitals would be associated with an increase in the management index of 1.6 standard deviations (using column (6)) and a 5.7 percentage point fall in AMI death rates (from column (10)). These calculations imply that the effects we identify are of economic as well as statistical significance.

\section{Mechanisms}

There are several routes by which competition could improve management practices. The first is simply through competition for patients. When a General Practitioner (the local "gatekeeper physician” for patients) refers a patient to a hospital for treatment she has the flexibility to refer the patient to any local hospital. Having more local hospitals gives greater choice for General Practitioners and so greater competition for hospitals. Since funding follows patients in the NHS, hospitals are keen to win patient referrals as this has private benefits for senior managers (e.g. better pay and conditions) and reduces the probability that they will be fired. The second mechanism is yardstick competition: with more local hospitals CEO performance is easier to evaluate because yardstick competition is stronger. The UK government actively undertakes yardstick competition, publishing summary measures of performance on all hospitals and punishing managers of poorly performing hospitals by dismissal (Propper et al, 2010).

Finally, it might be that a greater number of hospitals improve management quality not through competition, as we have assumed, but rather via input markets. Good managers will find markets with a higher density of hospitals to be a more attractive labor market. Hospitals with more rivals will therefore be able to hire better managers, who will help to increase the quality of management practices. We think this mechanism is less likely as managers are relatively mobile across England.

\section{CONCLUSIONS}

In this paper we investigate the impact of competition on hospital management and performance. We have described a new methodology for quantifying the quality of management practices in the hospital sector and implemented this survey tool in two thirds of the acute hospitals in England. We found that our measure of management quality was robustly associated with better hospital outcomes across mortality rates and other indicators of hospital performance. 
We then exploit the UK's centralized public hospital system to provide an instrumental variable for hospital competition. We use the share of marginal political constituencies around each hospital as an instrumental variable for the number of nearby competing hospitals. This works well because in the UK politicians almost never allow hospitals in politically marginal constituencies to close down, leading to higher levels of hospital competition in areas with more marginal constituencies. We find that more hospital competition appears to cause improved hospital management (and lower death rates). This suggests public sector competition is useful for improving management practices in the public sector.

In terms of future work, a drawback of our paper is that it is cross sectional since the management data is only available for a single year. We are collecting a second wave of the panel, however, which will enable us to investigate whether recent policy changes encouraging more competition have had an effect on hospital performance. Second, it would be interesting to expand our sample to look at healthcare management in other countries. We have piloted some work along these lines and plan to implement this in the US and other nations. Finally, examining how hospitals of different management quality and ownership respond differentially to shocks could be very revealing (Duggan, 2000).

\section{REFERENCES}

Besley, Timothy, Torsten Persson and Daniel M. Sturm (2005) "Political Competition and Economic Performance: Theory and Evidence from the United States”, NBER Working Paper No. W11484.

Bloom, Nicholas and John Van Reenen (2007) "Measuring and Explaining Management practices across firms and nations”, Quarterly Journal of Economics, Vol. 122, No. 4: 1351-1408.

Bloom, Nicholas and John Van Reenen (2010) "Human resource management and productivity", forthcoming in Ashenfelter, Orley and David Card (editors) Handbook of Labor Economics Volume $I V$.

Bloom, Nicholas, Christos Genakos, Raffaella Sadun, and John Van Reenen (2009) "Does Management Matter? New Empirics and old theories”, LSE/Stanford mimeo

Clark, Andrew E. and Carine Milcent (2008) "Keynesian Hospitals? Public Employment and Political Pressure”, Paris School of Economics Working Paper No. 2008 - 18. 
Cooper, Zack, Stephen Gibbons, Simon Jones and Alistair McGuire (2010) "Does Hospital Competition Save Lives? Evidence from the English Patient Choice Reforms”, LSE mimeo

Crewe, Martin (2005) “The opinion polls: the election they got (almost) right”, Parliamentary Affairs, 58 (4) pp 684-698.

Cutler, David M. and Jill R. Horwitz (1999) "Converting Hospitals from Not-For-Profit to For-Profit Status: Why and What Effects?” in D. Cutler (ed.) The Changing Hospital Industry: Comparing Not-For-Profit and For-Profit Institutions, Chicago: University of Chicago Press and NBER.

Cutler, David, Robert Huckman, and Jonathan Kolstad (2009) "Input constraints and the efficiency of entry: lessons from cardiac surgery", forthcoming the American Economic Journal: Economic Policy.

Department of Health (2008) High Quality for All: NHS Next Steps Review Final Report.

Dranove, David and Mark Satterthwaite (2000) "The industrial organization of healthcare markets" in Culyer, A. and Newhouse, J. (eds) The Handbook of Health Economics, Amsterdam: North Holland

Duggan, Mark (2000) “Hospital Ownership and Public Medical Spending” Quarterly Journal of Economics, November 1243-1374.

Duggan, Mark (2002) Hospital Market Structure and the Behavior of Not-For-Profit Hospitals The RAND Journal of Economics, Vol. 33, No. 3 (Autumn, 2002), pp. 433-446.

Fabrizio, Kira, Rose, Nancy and Wolfram, Katherine (2007), "Do markets reduce costs? Assessing the impact of regulatory restructuring on US electricity generating efficiency", American Economic Review, vol. 97, pp 1250-1277.

Farrar, Shelley, Yi Deokhee, Matt Sutton, Martin Chalkley, Jon Sussex and Anthony Scott (2007) "A National Evaluation of Payment by Results" Report to the Department of Health, November 2007.

Foster, Lucia, John Haltiwanger, and Chad Syverson (2008) "Reallocation, Firm Turnover, and Efficiency: Selection on Productivity or Profitability?” American Economic Review, 98(1), 394-425.

Gaynor, Martin (2004) "Competition and Quality in Health Care Markets. What Do We Know? What Don’t We Know?” Economie Publique 15: 3-40.

Gaynor, Martin and Deborah Haas-Wilson (1999) "Change, Consolidation amd Competition in Health Care Markets”, Journal of Economic Perspectives, 13, 141-164

Gaynor, Martin, Carol Propper, and Rodrigo Morrenes Serra (2010) "Death by Market Power: Reform, Competition and Patient Outcomes in the NHS. Mimeo, CMPO, Bristol University.

Hall, Robert and Chad Jones (2007) “The Value of Life and the Rise in Health Spending” Quarterly Journal of Economics, 122(1), 39-72. 
Healthcare Commission (2006) “The annual Health Check in 2006/2007”. http://www.healthcarecommission.org.uk/_db/_documents/The_annual_health_check_in_2006_200 7_assessing_and_rating_the_NHS_200609225143.pdf.

Hensher, Martin and Edwards, Nigel (1999) "Hospital provision, activity and productivity in England and Wales since the 1980s” British Medical Journal, 319, 911-914.

Jacobs, Rowena, Steve Martin, Maria Goddard, Hugh Gravelle and Peter Smith (2006) "Exploring the determinants of NHS performance ratings: lessons for performance assessment systems" Journal of Health Services Research and Policy, 7(4), 211-217.

Kessler, Daniel P. and Mark B. McClellan (2000) “Is Hospital Competition Socially Wasteful?” Quarterly Journal of Economics 115 (May): 577-615.

Lindbeck, Assar and Jorgen Weibull (1987) "Balanced-Budget Redistribution as the Outcome of Political Competition”, Public Choice, 52, 273-297.

List, John A. and Daniel M. Sturm (2006) "How Elections Matter: Theory and Evidence from Environmental Policy” Quarterly Journal of Economics, 121(November): 1249-1281.

Lizzeri, Alessandro and Nicola Persico (2001) "The Provision of Public Goods under Alternative Electoral Incentives”, American Economic Review, Vol. 91(1), 225-239.

McConnell, John, Kim Hoffman, Andrew Quanbeck, and Dennis McCartny (2009) "Management practices in substance abuse treatment programs" forthcoming Journal of Substance Abuse Treatment.

Milesi-Ferretti, Gian-Maria., Roberto Perotti and Massimo Rostagno (2002) "Electoral Systems and Public spending” Quarterly Journal of Economics, 117(2), 609-657.

Nagler, Jonathan and Jan Leighley (1992) "Presidential Campaign Expenditure: Evidence on Allocations and Effects”, Public Choice, 73, 319-333.

Nickell, Steve (1996) “Competition and Corporate Performance” Journal of Political Economy, CIV (4), 724-746.

Office for National Statistics (2008), UK Centre for the Measurement of Government Activity, Expenditure on Healthcare in the UK, April 2008, http://www.statistics.gov.uk/articles/nojournal/ExpenditureonHealth08.pdf.

Persson, Torsten and Guido Tabellini (1999), "The Size and Scope of Government: Comparative Politics with Rational Politicians”, European Economic Review, 43, 699-735.

Propper, Carol and John Van Reenen (2010) “Can Pay Regulation Kill? Panel Data evidence on the effect of Labor markets on hospital performance” Journal of Political Economy 118(2), 222-273

Propper, Carol, Simon Burgess and Denise Gossage (2008) "Competition and Quality: Evidence from the NHS Internal Market 1991-99” Economic Journal 118, 138-170. 
Propper, Carol, Matt Sutton, Carolyn Whitnall, and Frank Windmeijer (2010) "Incentives and Accountability in Hospital Care: Evidence from a Natural Experiment” forthcoming, Journal of Public Economics.

Schmidt, Klaus (1997) "Managerial Incentives and Product Market Competition" Review of Economic Studies 64(2) 191-213

Schmitz, James (2005). "What Determines Productivity? Lessons from the Dramatic Recovery of the U.S. and Canadian Iron Ore Industries following Their Early 1980s Crisis.” Journal of Political Economy, 113(3), 582-625.

Silverman, Elaine and Jonathan Skinner, (2001) “Are For-Profit Hospitals Really Different? Medicare ‘Upcoding’ and Market Structure” NBER Working paper No. W8133.

Sloan, F (2000) "Not-for-profit ownership and hospital behaviour" in Culyer, A J and Newhouse, J (eds) Handbook of Health Economics pp 1141-1174. Elsevier: Amersterdam.

Smith, Peter (2002) “Performance management in British health care: will it deliver?” Health Affairs 21(3), 103-115.

Stromberg, David (2008), "How the Electoral College Influences Campaigns and Policy: The Probability of Being Florid”, American Economic Review, 98(3), 769-807.

Syverson, Chad (2004). "Market Structure and Productivity: A Concrete Example.” Journal of Political Economy, 112(6): 1181-1222.

Syverson, Chad (2010), “What determines productivity?” mimeo, University of Chicago 
Table 1: Means and Standard Deviations of Variables

Variable

Management Quality (non-z-scored)

Average Management Score

Average Operations Score

Average Monitoring Score

Average Targets Score

Average Incentives Management Score
Mean Standard Dev. Observations

2.57

0.66

0.95

0.75

0.78

0.70

2.35

17.08

7.56

0.84

2,667

0.64

2.81

0.13

0.68

0.98

0.00

6.89

6.92

9.68

8.49

161

161

4.82

10.91

14.02

21.54

18.84

23.23

42.29

13.98

21.1

3.50

40.9

3.79

161

161

34.16

47.57

161

11.80

32.36

13.56

50.38

31.7

25.98

8.37

4.51

138

0.41

930

2.65

1.30
2.48

18,137

9,525

90.18

52.26

1,498

800

2.01

161

161

161

161

161

156

160

160

160

161

160

161

161

\section{1}

161

161

161

2.65
161

161

120

152

152

161

161

161

Number of sites 
Table 2: Hospital Performance and management practices

\begin{tabular}{|c|c|c|c|c|c|c|c|c|}
\hline Dependent Variable: & $\begin{array}{c}(1) \\
\text { Mortality rate } \\
\text { from } \\
\text { emergency } \\
\text { AMI }\end{array}$ & $\begin{array}{c}(2) \\
\text { Mortality } \\
\text { rate from all } \\
\text { emergency } \\
\text { surgery }\end{array}$ & $\begin{array}{c}\text { (3) } \\
\text { Waiting } \\
\text { list } \\
(1000 \\
\text { patients) }\end{array}$ & $\begin{array}{c}(4) \\
\text { MRSA } \\
\text { infection } \\
\text { rate }\end{array}$ & $\begin{array}{c}(5) \\
\text { Operating } \\
\text { Margin }\end{array}$ & $\begin{array}{c}(6) \\
\text { Intention of } \\
\text { staff to leave } \\
\text { in next } 12 \\
\text { months }\end{array}$ & $\begin{array}{c}\text { (7) } \\
\text { Health Care } \\
\text { Commission } \\
\text { (HCC) overall } \\
\text { rating }\end{array}$ & $\begin{array}{c}(8) \\
\text { “Pseudo” } \\
\text { HCC rating }\end{array}$ \\
\hline Mean & 17.08 & 2.21 & 4.90 & 1.61 & 1.27 & 2.70 & 2.25 & 0 \\
\hline $\begin{array}{l}\text { A. Overall Management } \\
\text { Practices Score }\end{array}$ & $\begin{array}{l}-0.664 * \\
(0.395)\end{array}$ & $\begin{array}{c}-0.103^{* *} \\
(0.045)\end{array}$ & $\begin{array}{c}-0.204^{* *} \\
(0.099)\end{array}$ & $\begin{array}{l}-0.128 * \\
(0.070)\end{array}$ & $\begin{array}{c}0.005 \\
(0.003)\end{array}$ & $\begin{array}{l}-0.028 * \\
(0.016)\end{array}$ & $\begin{array}{c}0.127 * * \\
(0.053)\end{array}$ & $\begin{array}{c}0.268 * * * \\
(0.098)\end{array}$ \\
\hline B. Operations & $\begin{array}{l}-0.030 \\
(0.352)\end{array}$ & $\begin{array}{l}-0.056 * \\
(0.030)\end{array}$ & $\begin{array}{l}-0.037 \\
(0.089)\end{array}$ & $\begin{array}{c}-0.116^{* *} \\
(0.057)\end{array}$ & $\begin{array}{c}0.005 \\
(0.004)\end{array}$ & $\begin{array}{l}-0.007 \\
(0.013)\end{array}$ & $\begin{array}{l}-0.039 \\
(0.047)\end{array}$ & $\begin{array}{l}0.180 * \\
(0.093)\end{array}$ \\
\hline C. Monitoring & $\begin{array}{l}-0.381 \\
(0.396)\end{array}$ & $\begin{array}{c}-0.076^{* *} \\
(0.038)\end{array}$ & $\begin{array}{l}-0.057 \\
(0.106)\end{array}$ & $\begin{array}{l}-0.036 \\
(0.068)\end{array}$ & $\begin{array}{l}-0.001 \\
(0.003)\end{array}$ & $\begin{array}{l}-0.006 \\
(0.012)\end{array}$ & $\begin{array}{c}0.068 \\
(0.050)\end{array}$ & $\begin{array}{c}0.127 \\
(0.090)\end{array}$ \\
\hline D. Targets & $\begin{array}{c}-0.721^{* *} \\
(0.354)\end{array}$ & $\begin{array}{c}-0.088 * * \\
(0.044)\end{array}$ & $\begin{array}{c}-0.231^{* *} \\
(0.097)\end{array}$ & $\begin{array}{l}-0.114^{*} \\
(0.065)\end{array}$ & $\begin{array}{c}0.004 \\
(0.003)\end{array}$ & $\begin{array}{c}-0.032 * * \\
(0.016)\end{array}$ & $\begin{array}{c}0.132 * * * \\
(0.050)\end{array}$ & $\begin{array}{l}0.165^{*} \\
(0.090)\end{array}$ \\
\hline E. People Management & $\begin{array}{c}-0.804^{* *} \\
(0.393)\end{array}$ & $\begin{array}{l}-0.069 \\
(0.046)\end{array}$ & $\begin{array}{c}-0.224^{* *} \\
(0.100)\end{array}$ & $\begin{array}{l}-0.082 \\
(0.070)\end{array}$ & $\begin{array}{c}0.004 \\
(0.003)\end{array}$ & $\begin{array}{c}-0.032^{* *} \\
(0.016)\end{array}$ & $\begin{array}{c}0.195 * * * \\
(0.051)\end{array}$ & $\begin{array}{c}0.273 * * * \\
(0.095)\end{array}$ \\
\hline Observations & 140 & 157 & 160 & 160 & 161 & 160 & 161 & 161 \\
\hline \multicolumn{9}{|c|}{$\begin{array}{l}\text { Notes: } * * * \text { indicates significance at the } 1 \% \text { level; ** significance at } 5 \%, * \text { significance at } 10 \% \text {. Every cell constitutes a separate regression. The dependent variables in columns (1) } \\
\text { through (4) and (6) are generally considered to be "bad" whereas those in (5), ( } 7) \text { and (8) are "good" - see text for more details. Management scores are standardized across the } 18 \\
\text { questions in Appendix A. These are coefficients from OLS regressions with standard errors that are clustered at a hospital level below (the unit of observation is a management interview } \\
\text { with a service line in cardiology or orthopaedics across } 100 \text { public acute hospitals). All columns include controls for whether the respondent was a manager or clinician, } 9 \text { regional } \\
\text { dummies and the number of sites. Controls for case mix and total admissions are also included, but vary across columns (see text for discussion). All columns also include "noise controls" } \\
\text { comprising interviewer dummies and tenure of the interviewee, foundation trust status, share of managers with clinical degree and joint decision making dummy. The observations are } \\
\text { weighted by the inverse of the number of interviews with the same hospital. In Column (1) we drop hospitals with less than } 150 \text { AMI cases per year. Column (7) is average of HCC's } \\
\text { rating on resource use and quality of service. Column (8) is our self-constructed HCC rating based on several indicators. }\end{array}$} \\
\hline
\end{tabular}




\section{Table 3: The effect of Competition on Management Practices}

\begin{tabular}{|c|c|c|c|c|c|c|c|c|c|c|}
\hline Type of Regression & $\begin{array}{l}(1) \\
\text { OLS }\end{array}$ & $\begin{array}{c}(2) \\
\text { IV: First Stage }\end{array}$ & $\begin{array}{c}\text { (3) } \\
\text { IV: Second } \\
\text { Stage }\end{array}$ & $\begin{array}{c}(4) \\
\text { OLS }\end{array}$ & $\begin{array}{c}(5) \\
\text { IV: First } \\
\text { Stage }\end{array}$ & $\begin{array}{c}\text { (6) } \\
\text { IV: Second } \\
\text { Stage }\end{array}$ & $\begin{array}{c}(7) \\
\text { IV: First } \\
\text { Stage }\end{array}$ & $\begin{array}{l}(8) \\
\text { IV: Second } \\
\text { Stage }\end{array}$ & $\begin{array}{l}(9) \\
\text { OLS }\end{array}$ & $\begin{array}{c}(10) \\
\text { IV: Second } \\
\text { Stage }\end{array}$ \\
\hline Dependent variable & Management & $\begin{array}{l}\text { Number of } \\
\text { Competing } \\
\text { Hospitals }\end{array}$ & Management & Management & $\begin{array}{l}\text { Number of } \\
\text { Competing } \\
\text { Hospitals }\end{array}$ & Management & $\begin{array}{c}\text { Number of } \\
\text { Competing } \\
\text { Hospitals }\end{array}$ & Management & $\begin{array}{l}\text { Mortality rate } \\
\text { from } \\
\text { emergency } \\
\text { AMI }\end{array}$ & $\begin{array}{c}\text { Mortality rate } \\
\text { from } \\
\text { emergency } \\
\text { AMI }\end{array}$ \\
\hline $\begin{array}{l}\text { Number of Competing } \\
\text { Public Hospitals }\end{array}$ & $\begin{array}{c}0.121^{* *} \\
(0.058)\end{array}$ & & $\begin{array}{l}0.361 * \\
(0.215)\end{array}$ & $\begin{array}{l}0.120^{*} \\
(0.068)\end{array}$ & & $\begin{array}{c}0.543 * * \\
(0.220)\end{array}$ & & $\begin{array}{r}0.475 * * \\
(0.202)\end{array}$ & $\begin{array}{c}-1.099 * * \\
(0.486)\end{array}$ & $\begin{array}{l}-1.827 * \\
(1.037)\end{array}$ \\
\hline $\begin{array}{l}\text { Proportion of Labour } \\
\text { Marginal } \\
\text { Constituencies }\end{array}$ & & $\begin{array}{c}5.850 * * * \\
(1.553)\end{array}$ & & & $\begin{array}{c}5.156^{* * *} \\
(1.398)\end{array}$ & & $\begin{array}{c}5.296 * * * \\
(1.416)\end{array}$ & & & \\
\hline $\begin{array}{l}\text { Proportion of Non- } \\
\text { Labour Marginal } \\
\text { Constituencies }\end{array}$ & & & & & & & $\begin{array}{c}1.245 \\
(1.015)\end{array}$ & & & \\
\hline $\begin{array}{l}\text { F-statistic of excluded i } \\
\text { corresponding first stag }\end{array}$ & $\begin{array}{l}\text { nstrument in } \\
\text { e }\end{array}$ & 14.18 & & & 13.60 & & 7.36 & & & 8.94 \\
\hline General Controls & No & No & No & Yes & Yes & Yes & Yes & Yes & No & No \\
\hline AMI-specific controls & No & No & No & No & No & No & No & No & Yes & Yes \\
\hline Observations & 161 & 161 & 161 & 161 & 161 & 161 & 161 & 161 & 140 & 140 \\
\hline
\end{tabular}

Notes: *** indicates significance at the $1 \%$ level; ** significance at $5 \%, *$ significance at $10 \%$. Competition is measured as the number of hospitals in a $30 \mathrm{~km}$ radius around the hospital (the "catchment area") unless otherwise stated. A political constituency is defined as marginal if it was won by less than 5\% in the 1997 General Election (proportion of marginal constituencies is based on the catchment area). The Labour share of votes is the absolute share obtained by the Governing party in the 1997 UK General Election averaged over al constituencies in the catchment area. Standard errors are clustered at a hospital level (the unit of observation is a service line in cardiology or orthopaedics). All columns include controls for the total population and age profile (11 categories) in the catchment area, whether the hospital was a Foundation Trust and interviewer dummies (4). "General controls" include share of Labour votes, the number of political constituencies and average mortality in the catchment area; the tenure of the respondent and whether she was a manager or clinician, 9 regional dummies, the number of hospital sites, number of total admissions and the "case-mix" (age/gender profile of admissions), share of managers with a clinical degree and a dummy for whether there was joint decision making at the hospital level. "AMI specific controls" are those in Table 2 column (1). 
Figure 1: Governing (Labour) Party's Winning Margin and the Number of Acute Hospitals in a Political Constituency

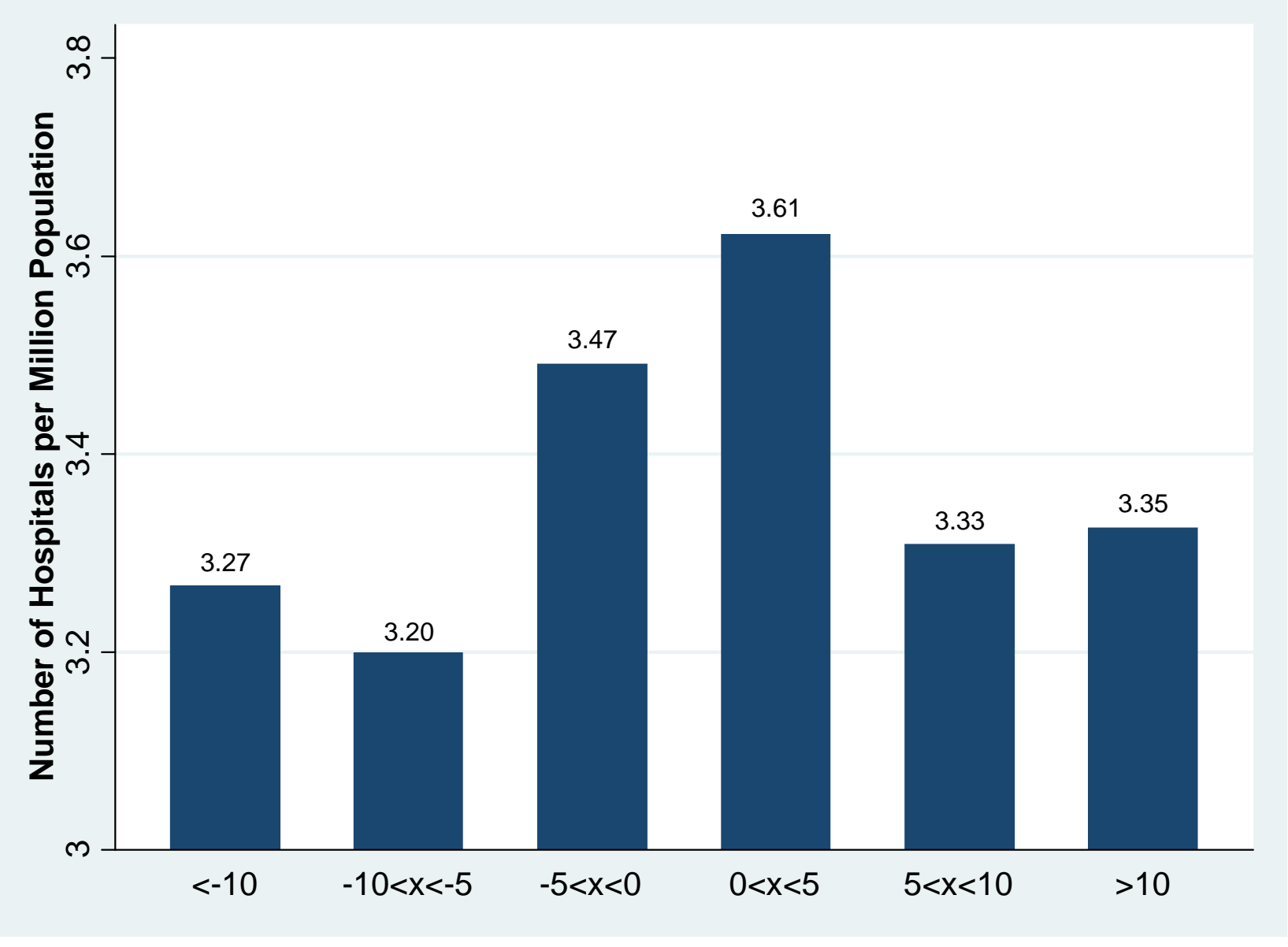

\section{Labour party's winning \% margin (1997)}

Notes: This figure plots the mean number of hospitals per 1 million people within a 30km radius of the centroid of a political constituency against the "winning margin" in 1997 of the governing party (Labour). When Labour is not the winning party, the margin is the negative of the difference between the winning party (usually Conservative) and the next closest party. The margin is denoted " $x$ ”. There are 528 political constituencies in England. 


\section{Figure 2: Management Score by quintiles of average HCC rating}

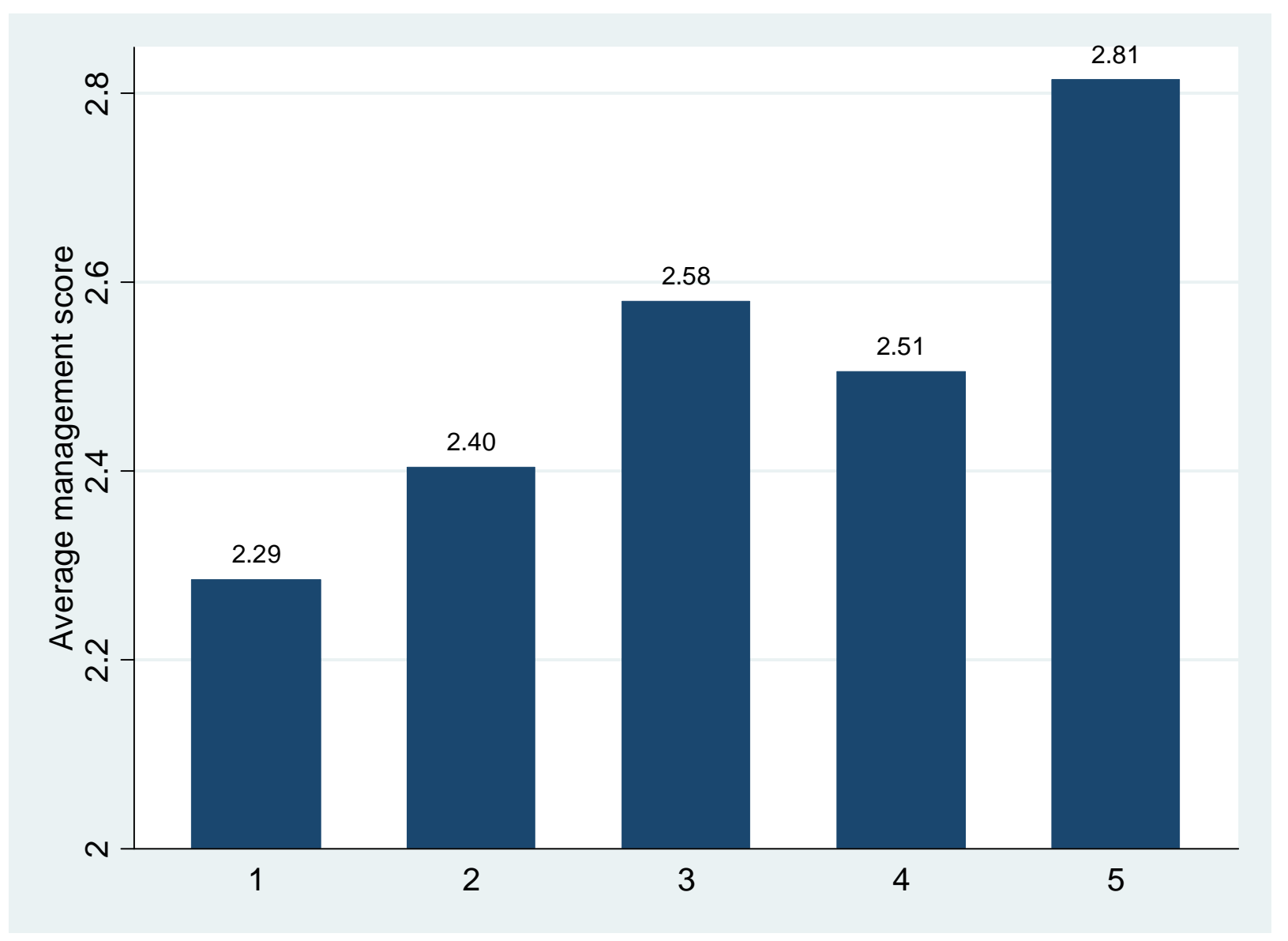

Notes: The Health Care Commission (HCC) is an NHS regulator who gives every hospital in England an aggregate performance score across seven domains (see Appendix B). We divide the HCC average score into quintiles from lowest score (first) to highest score (fifth) along the x-axis. We show the average management score (over all 18 questions) in each of the quintiles on the y-axis. The better performing hospitals have higher management scores. 


\section{Figure 3: Comparison of Management Scores in Hospitals and}

\section{Manufacturing Firms}

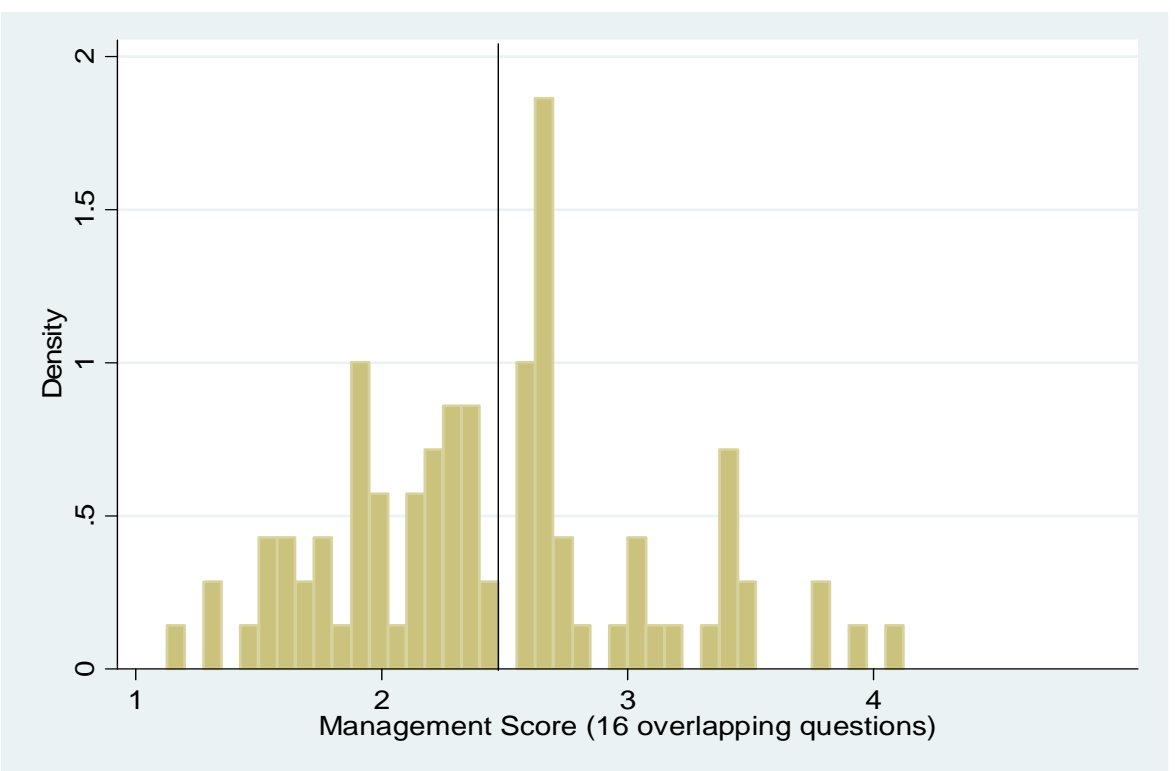

\section{Panel A}

Management Scores

in Hospitals

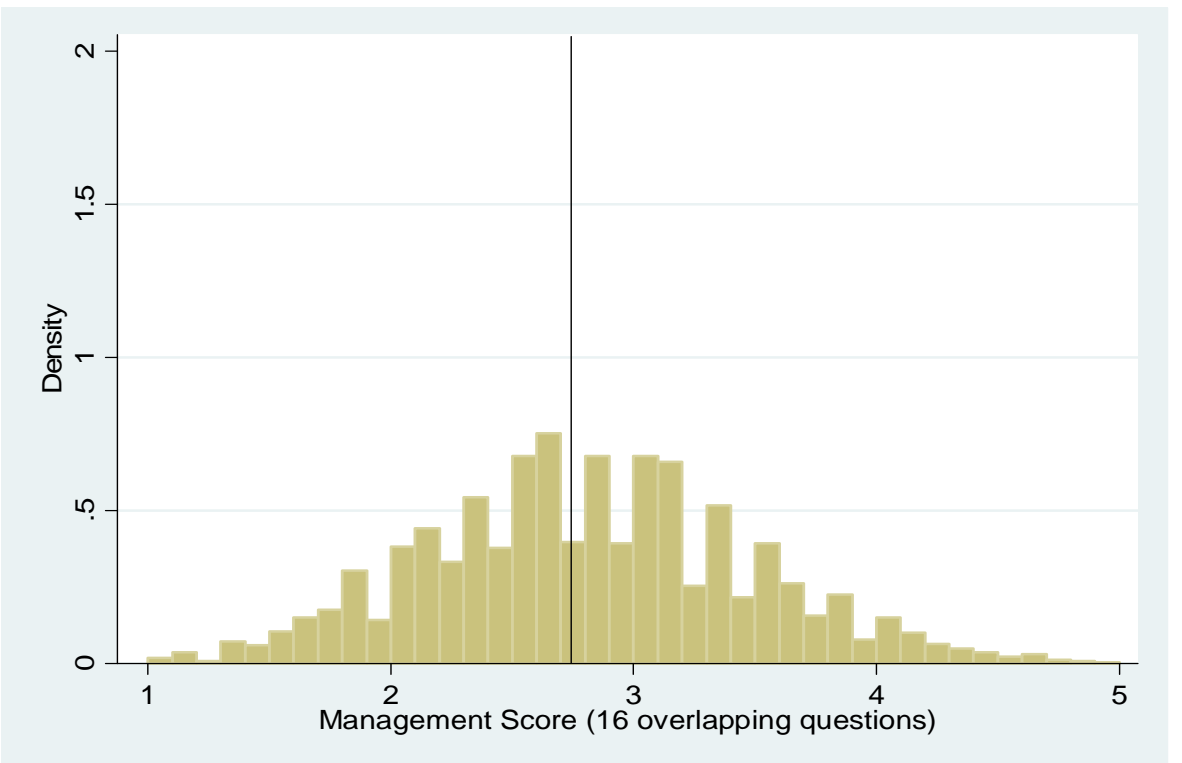

\section{Panel B:}

\section{Management Scores}

In Manufacturing Firms

Notes: These are the distributions of the management score for hospitals and manufacturing firms. Only establishments who have between 50 and 5000 employees and who are domestically owned (i.e. multinationals were dropped from the manufacturing sample) were used here. Also observations with a low reliability score (below 3) were dropped. The vertical line represents the average management score in each sample. Only the 16 questions for which manufacturing and healthcare are comparable (questions 3 to 18) were used. 


\section{APPENDIX A: MANAGEMENT PRACTICE INTERVIEW GUIDE \\ FOR THE HEALTHCARE SECTOR}

Any score from 1 to 5 can be given, but the scoring guide and examples are only provided for scores of 1, 3 and 5 . Multiple questions are used for each dimension to improve scoring accuracy.

\begin{tabular}{|c|c|c|c|}
\hline \multicolumn{4}{|c|}{ (1) Lay out of patient flow } \\
\hline \multicolumn{4}{|c|}{ Tests how well the patient pathway is configured at the infrastructure level and whether staff pro-actively improve their own work-place organisation } \\
\hline & a) Can you briefly describe the patient jou & ey or flow for a typical episode? & \\
\hline & b) How closely located are wards, theatres, & iagnostics centres and consumables? & \\
\hline & c) Has the patient flow and the layout of th & hospital changed in recent years? How frequen & do these changes occur and what are they driven by? \\
\hline & Score 1 & Score 3 & Score 5 \\
\hline Scoring grid: & $\begin{array}{l}\text { Lay out of hospital and organisation of } \\
\text { workplace is not conducive to patient flow, } \\
\text { e.g., ward is on different level from theatre, } \\
\text { or consumables are often not available in } \\
\text { the right place at the right time }\end{array}$ & $\begin{array}{l}\text { Lay out of hospital has been thought-through } \\
\text { and optimised as far as possible; work place } \\
\text { organisation is not regularly } \\
\text { challenged/changed (or vice versa) }\end{array}$ & $\begin{array}{l}\text { Hospital layout has been configured to optimize patient } \\
\text { flow; workplace organization is challenged regularly and } \\
\text { changed whenever needed }\end{array}$ \\
\hline
\end{tabular}

(2) Rationale for introducing standardisation/ pathway management

Test the motivation and impetus behind changes to operations and what change story was communicated

a) Can you take me through the rationale for making operational improvements to the management of patient pathway? Can you describe a recent example?

b) What factors led to the adoption of these practices?

c) Who typically drives these changes?

\section{Score 1}

Scoring grid: $\quad$ Changes were imposed top down or because other departments were making (similar) changes, rationale was not communicated or understood

\section{Score 3}

Changes were made because of financial pressure and the need to save money or as a (short-term) measure to achieve government targets

\section{Score 5}

Changes were made to improve overall performance, both clinical and financial, with buy-in from all affected staff groups. The changes were communicated in a coherent 'change story' 
Tests process for and attitudes to continuous improvement and whether things learned are captured/documented

a) How do problems typically get exposed and fixed?

b) Talk me through the process for a recent problem that you faced

c) How do the different staff groups get involved in this process? Can you give examples?

\section{Score 1}

Scoring grid:

No, process improvements are made when problems occur, or only involve one staff group

\section{Score 3}

Improvements are made irregular meetings involving all staff groups, to improve

performance in their area of work (e.g., ward or theatre)

\section{Score 5}

Exposing problems in a structured way is integral to individuals' responsibilities and resolution involves all staff groups, along the entire patient pathway as a part of regular business processes rather than by extraordinary effort/teams

\section{(4) Performance tracking}

Tests whether performance is tracked using meaningful metrics and with appropriate regularity

a) What kind of performance indicators would you use for performance tracking?

b) How frequently are these measured? Who gets to see these data?

c) If I were to walk through your hospital wards and theatres, could I tell how you were doing against your performance goals?

\section{Score 1}

Scoring grid: $\quad$ Measures tracked do not indicate directly if overall objectives are being met, e.g., only government targets tracked. Tracking is an ad-hoc process (certain processes aren't tracked at all).

\section{Score 3}

Most important performance indicators are tracked formally; tracking is overseen by senior staff.

\section{Score 5}

Performance is continuously tracked and communicated against most critical measures, both formally and informally, to all staff using a range of visual management tools

\section{(5) Performance review}

Tests whether performance is reviewed with appropriate frequency and communicated with staff

a) How do you review your KPI's?

b) Tell me about a recent meeting

c) Who is involved in these meetings? Who gets to see the results of this review?

d) What is the follow-up plan?

\section{Score 1}

Scoring grid

Performance is reviewed infrequently or in an un-meaningful way e.g. only success or failure is noted

\section{Score 3}

Performance is reviewed periodically with both successes and failures identified.

Results are communicated to senior staff. No clear follow up plan is adopted.

\section{Score 5}

Performance is continually reviewed, based on the indicators tracked. All aspects are followed up to ensure continuous improvement. Results are communicated to all staff. 


\begin{tabular}{|c|c|c|c|}
\hline \multicolumn{4}{|c|}{ (6) Performance dialogue } \\
\hline \multicolumn{4}{|c|}{ Tests the quality of review conversations } \\
\hline & \multirow{3}{*}{\multicolumn{3}{|c|}{$\begin{array}{l}\text { How are these meetings structured? } \\
\text { During these meetings do you find that you generally have enough data? } \\
\text { What type of feedback occurs in these meetings? }\end{array}$}} \\
\hline & & & \\
\hline & & & \\
\hline & Score 1 & Score 3 & Score 5 \\
\hline Scoring grid: & $\begin{array}{l}\text { The right information for a constructive } \\
\text { discussion is often not present or the quality } \\
\text { is too low; conversations focus overly on } \\
\text { data that is not meaningful. Clear agenda is } \\
\text { not known and purpose is not explicitly. } \\
\text { Next steps are not clearly defined }\end{array}$ & $\begin{array}{l}\text { Review conversations are held with the } \\
\text { appropriate data present. Objectives of } \\
\text { meetings are clear to all participating and a } \\
\text { clear agenda is present. Conversations do } \\
\text { not, drive to the root causes of the problems, } \\
\text { next steps are not well defined }\end{array}$ & $\begin{array}{l}\text { Regular review/performance conversations focus on } \\
\text { problem solving and addressing root causes. Purpose, } \\
\text { agenda and follow-up steps are clear to all. Meetings are } \\
\text { an opportunity for constructive feedback and coaching }\end{array}$ \\
\hline
\end{tabular}

Tests whether differing levels of (personal) performance lead to different consequences (good or bad)

a) Let's say you've agreed to a follow up plan at one of your meetings, what would happen if the plan weren't enacted?

b) How long is it between when a problem is identified to when it is solved? Can you give me a recent example?

c) How do you deal with repeated failures in a specific sub-specialty or cost area?

\section{Score 1}

Scoring grid:

Failure to achieve agreed objectives does

not carry any consequences

\section{Score 3}

Failure to achieve agreed results is tolerated

for a period before action is taken
Score 5

A failure to achieve agreed targets drives retraining in identified areas of weakness or moving individuals to where their skills are appropriate

\begin{tabular}{l} 
(8) Target balance \\
\hline Test whether targets cover a sufficiently broad set of metrics \\
$\qquad \begin{array}{l}\text { a) What types of targets are set for the hospital? What are the goals for your specialty? } \\
\text { b) Tell me about goals that are not set externally (e.g. by the government, regulators). }\end{array}$
\end{tabular}

\section{Score 1}

Scoring grid: b) Tell me about goals that are not set externally (e.g. by the government, regulators).

\section{Score 3}

oals focussed only on government targets and achieving the budget
Goals are balanced set of targets (including quality, waiting times, operational efficiency, and financial balance). Goals form part of the appraisal for senior staff only or do not extend to all staff groups. Real interdependency is not well understood

\section{Score 5}

Goals are a balanced set of targets covering all four dimensions (see left). Interplay of all four dimensions is understood by senior and junior staff (clinicians as well as nurses and managers) 
Tests whether targets are tied to hospital/Trust objectives and how well they cascade down the organisation

a) What is the motivation behind your goals?

b) How are these goals cascaded down to the different staff groups or to individual staff members?

c) How are your targets linked to hospital performance and its goals?

\section{Score 1}

Scoring grid:

Goals do not cascade down the organisation

\section{Score 3}

Goals do cascade, but only to some staff groups, e.g., nurses only
Score 5

Goals increase in specificity as they cascade, ultimately defining individual expectations, for all staff groups

\begin{tabular}{l} 
(10) Time horizon of targets \\
\hline Tests whether hospital/Trust has a '3 horizons' approach to planning and targets \\
a) What kind of time scale are you looking at with your targets? \\
b) Which goals receive the most emphasis? \\
c) Are the long term and short term goals set independently? \\
d) Could you meet all your short-run goals but miss your long-run goals? \\
Score 1
\end{tabular}

Scoring grid

Top staff's main focus is on short term targets
There are short and long term goals for all evels of the organisation. As they are set independently, they are not necessarily linked to each other

\section{Score 5}

Long term goals are translated into specific short term targets so that short term targets become a 'staircase' to reach long term goals

\section{(11) Target stretch}

Tests whether targets are appropriately difficult to achieve

a) How tough are your targets? Do you feel pushed by them?

b) On average, how often would you say that you meet your targets?

c) Do you feel that on targets all specialties, departments or staff groups receive the same degree of difficulty? Do some groups get easy targets?

d) How are the targets set? Who is involved?

\section{Score 1}

Scoring grid:
Goals are either too easy or impossible to achieve, at least in part because they are set with little clinician involvement, e.g. simply off historical performance

\section{Score 3}

In most areas, senior staff push for aggressive goals based, e.g., on external benchmarks, but with little buy-in from clinical staff. There are a few sacred cows that are not held to the same standard

\section{Score 5}

Goals are genuinely demanding for all parts of the organisation and developed in consultation with senior staff, e.g., to adjust external benchmarks appropriately 


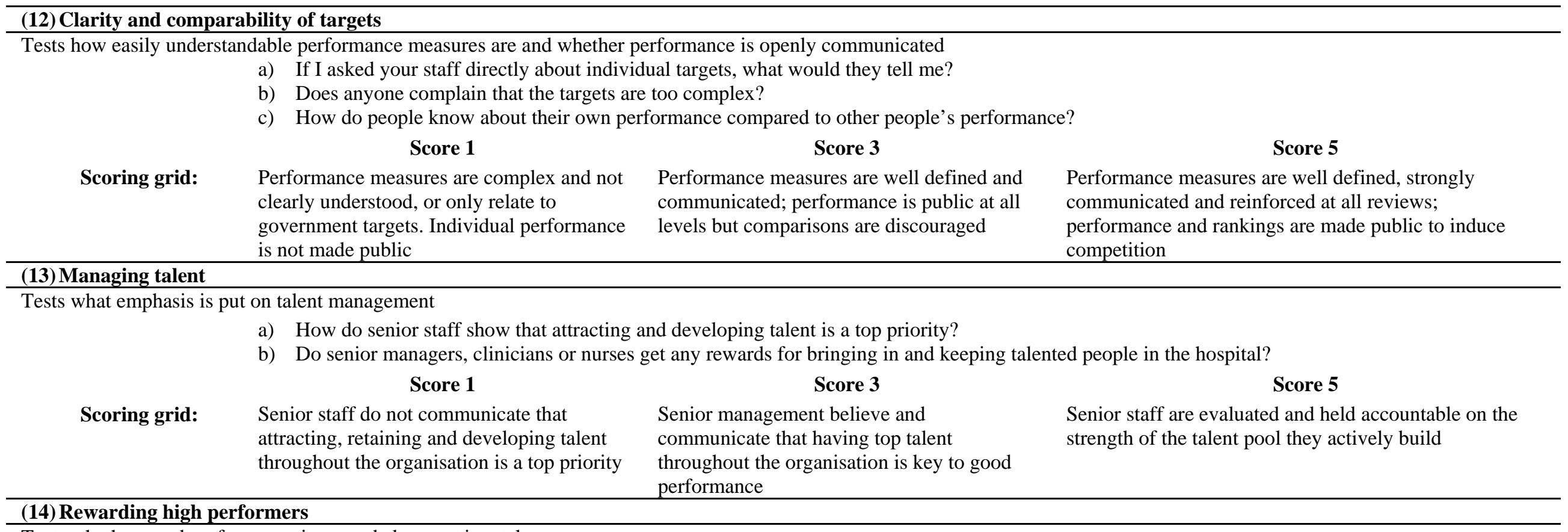

(14) Rewarding high performers

Tests whether good performance is rewarded proportionately

a) How does your appraisal system work? Tell me about your most recent round.

b) Are there any non-financial or financial (bonuses) rewards for the best performers across all staff groups?

c) How does the bonus system work?

d) How does your reward system compare to that at other comparable hospitals?

\section{Score 1}

Scoring grid

People are rewarded equally irrespective of performance level

\section{Score 3}

There is an evaluation system for the awarding of performance related rewards that are non-financial (beyond progression through nursing grades or clinical excellence awards for doctors) at the individual level (but rewards are always or never achieved)

\section{Score 5}

There is an evaluation system for the awarding of performance related rewards, including personal financial rewards 


\begin{tabular}{|c|c|c|c|c|}
\hline \multicolumn{5}{|c|}{ (15) Removing poor performers } \\
\hline \multicolumn{5}{|c|}{ Tests whether hospital is able to deal with underperformers } \\
\hline & a) & \multicolumn{3}{|c|}{ If you had a clinician or a nurse who could not do his job, what would you do? Could you give me a recent example? } \\
\hline & b) & \multicolumn{3}{|c|}{ How long would underperformance be tolerated? } \\
\hline & c) & \multicolumn{3}{|c|}{ Do you find staff members who lead a sort of charmed life? Do some individuals always just manage to avoid being fixed/fired? } \\
\hline & & Score 1 & Score 3 & Score 5 \\
\hline Scoring grid: & $\begin{array}{l}\text { Poo } \\
\text { thei }\end{array}$ & $\begin{array}{l}\text { r performers are rarely removed from } \\
\text { positions }\end{array}$ & $\begin{array}{l}\text { Suspected poor performers stay in a position } \\
\text { for a few years before action is taken }\end{array}$ & $\begin{array}{l}\text { We move poor performers out of the hospital/department } \\
\text { or to less critical roles as soon as a weakness is identified }\end{array}$ \\
\hline
\end{tabular}

\section{(16) Promoting high performers}

Tests whether promotion is performance based

a) Tell me about your promotion system?

b) What about poor performers? What happens with them? Are there any examples you can think of?

c) How would you identify and develop your star performers?

d) Are better performers likely to promote fasters or are promotions given on the basis of tenure/seniority?

\section{Score 1}

Scoring grid:
People are promoted primarily on the basis of tenure

\section{Score 3}

People are promoted upon the basis of performance (across more than one

dimension, e.g., isn’t related only to research

or clinical excellence)

\section{(17) Attracting talent}

Tests how strong the employee value proposition is

a) What makes it distinctive to work at your hospital, as opposed to your other similar hospitals?

b) If I were a top nurse or clinician and you wanted to persuade me to work at your hospital, how would you do this?

c) What don't people like about working at your hospital?

\section{Score 1}

Scoring grid: $\quad$ Our competitors offer stronger reasons for talented people to join their hospitals

\section{Score 3}

Our value proposition to those joining our department is comparable to those offered by others hospitals

\section{Score 5}

We actively identify, develop and promote our top performers

\section{(18) Retaining talent \\ Tests whether hospital/Trust will go out of its way to keep its top talent}

a) If you had a top performing manager, nurse or clinician that wanted to leave, what would the hospital do?

b) Could you give me an example of a star performer being persuaded to stay after wanting to leave?

c) Could you give me an example of a star performer who left the hospital without anyone trying to keep them?

\section{Score 1}

Scoring grid:

\section{Score 3}

We usually work hard to keep our top talent
Score 5

We provide a unique value proposition to encourage talented people join our department above our competitors 


\section{APPENDIX B: DATA}

Sample

The main sampling frame was all acute public sector hospitals (NHS “trusts”) in England. ${ }^{41}$ There were 174 such units in 2006, but we dropped hospitals without orthopaedics or cardiology departments (e.g. specialist eye hospitals) so this left us with a sample of 164 possible hospital trusts. We obtained 161 usable responses from 100 hospital trusts which represented $61 \%$ of the frame. We sought responses from up to four senior employees in each hospital: a manager and a clinician from two service lines (cardiology and orthopaedics). Table 1 shows the data is evenly split between the specialities (52\% cardiology and $48 \%$ orthopaedics), but that it was harder to obtain interviews with the physicians than managers (80\% of the respondents were managers). We interviewed one respondent in 53 hospitals, two respondents in 34 hospitals, three respondents in 12 hospitals and four respondents in one hospital. The correlation of the average management score across responders within the same hospital was high (0.53) as shown in Figure A1.

We examined evidence for selection bias by estimating probit models of whether a trust responded on the observable characteristics used in our analyses. Table B2 contains the results of this exercise. There is no significant correlation at the $5 \%$ level between sample response and any of the performance measures or covariates and only one (from 16) of the indicators are significant at the $10 \%$ level. This suggests that there was little systematic response bias.

In the regressions all interviews with many unanswered questions (three or more) are excluded as the information obtained is unlikely to be reliable. This excludes 3 interviews out of 164 . We weight regressions by the inverse of the number of interviews so that hospitals with multiple responses are weighted less (we also cluster standard errors at the hospital level).

\section{Construction of the Pseudo HCC Rating}

In column (8) of Table 2 we reported our best effort to reconstruct the HCC's rating. Although the exact method of creating the HCC ratings is not publicly known the Appendix of the HCC's "Annual Health Check 2006/2007" brochure mentions seven "domains” in which the hospitals need to achieve certain standards in order to achieve a high score.

These domains are: safety, clinical and cost effectiveness, governance, patient focus, accessible and responsive care, public health, and care environment and amenities. From the datasets described above we choose eight variables which capture the requirements of these different domains. Infection rates and re-admission risk are chosen to represent the "safety" aspect; operational margin and income per medical full time equivalent capture the financial side; patient satisfaction covers the "patient focus" domain. Waiting times and average length of stay fall into the category "accessible and responsive care" and information on job satisfaction from the NHS staff survey is used to represent the "care environment and amenities” domain.

\footnotetext{
${ }^{41}$ A trust can consist of more than one site (as a firm can consist of more than one plant). The median number of sites was 2 with a range from 1 to 10 .
} 


\section{Table B1: Data Sources for hospital performance data}

\begin{tabular}{|c|c|c|}
\hline Variable & Notes & Source \\
\hline $\begin{array}{l}\text { Mortality within } 28 \text { days of emergency } \\
\text { admission for AMI (in hospital and out of } \\
\text { hospital) }\end{array}$ & $\begin{array}{l}\text { - During financial quarter } \\
\text { - Defined according to NHS mortality } \\
\text { rate Performance indicators (PIs) for } \\
\text { 2001/02 }\end{array}$ & $\begin{array}{l}\text { ONS death records linked with Hospital Episode Statistics (HES), The NHS } \\
\text { Information Centre for health and social care. }\end{array}$ \\
\hline $\begin{array}{l}\text { Mortality within } 30 \text { days of surgery for } \\
\text { selected emergency procedures. }\end{array}$ & $\begin{array}{l}\text { - During financial quarter } \\
\text { rate PIs for 2001/02 } \\
\text { rated according to NHS mortality } \\
\end{array}$ & $\begin{array}{l}\text { ONS death records linked with Hospital Episode Statistics (HES), The NHS } \\
\text { Information Centre for health and social care. }\end{array}$ \\
\hline Waiting list size & $\begin{array}{l}\text { - At start of quarter (as proxied by end } \\
\text { of previous quarter) }\end{array}$ & Department of Health: Provider based waiting times/list statistics ${ }^{\mathrm{a}}$ \\
\hline MRSA rates & $\begin{array}{l}\text { - } \text { During 6-month period } \\
\text { - } 2001 / 02 \text { (q1) to 2004/05 (q3) }\end{array}$ & $\begin{array}{l}\text { Health Protection Agency: Half-yearly reporting results for clostridium difficile } \\
\text { infections and MRSA bacteraemia }\end{array}$ \\
\hline $\begin{array}{ll}\text { Financial Indicators: } \\
\text { - } \quad \text { Income per spell } \\
\text { - Income per bed } \\
\text { - } \quad \text { Operating Margin }\end{array}$ & & Trust Financial Returns \\
\hline Probability of leaving in next 12 months & $\begin{array}{l}\text { Respondents are asked to rate } \\
\text { chances of leaving on a } 1 \text { to } 5 \text { scale. }\end{array}$ & $\begin{array}{l}\text { NHS Staff Survey }{ }^{c}(2006) .128,328 \text { NHS staff responded and results are reported as } \\
\text { average of scale by each trust }\end{array}$ \\
\hline Healthcare Commission rating ${ }^{\mathrm{d}}$ & $\begin{array}{l}\text { All trusts are scored on a scale of } 1 \\
\text { to } 4 \text { on "resource use" and quality of } \\
\text { "care" }\end{array}$ & $\begin{array}{l}\text { Our main indicator averages over the two measures and standardizes. We also } \\
\text { construct our own "pseudo" HCC rating from the underlying indicators (see } \\
\text { Appendix B for full description) }\end{array}$ \\
\hline Local authority all cause mortality rates & - Calendar year & Office of National Statistics 1995-2004 \\
\hline $\begin{array}{l}\text { Casemix of admissions: } \\
\text { These are specific to the conditions (AMI, } \\
\text { surgery, etc.) considered. For the general } \\
\text { performance indicators (like HCC rating) } \\
\text { we use case mix for all admitted patients. }\end{array}$ & $\begin{array}{l}\text { Proportion of admitted patients in } \\
\text { each sex-specific age band. } 11 \text { age } \\
\text { categories: } 0-15,16-45,46-50,51- \\
\text { 55, 56-60, 61-65, 66-70, 71-75, 76- } \\
\text { 80, 81-85, >85 and two genders, so } \\
\text { up to } 22 \text { controls. }\end{array}$ & $\begin{array}{l}\text { Hospital Episode Statistics (HES), The NHS Information Centre for health and } \\
\text { social care. }\end{array}$ \\
\hline
\end{tabular}

Notes: MRSA is Methicillin-Resistant Staphylococcus Aureus 
${ }^{\mathrm{a}}$ http://www.performance.doh.gov.uk/nhsperformanceindicators/2002/trdca t.doc. ${ }^{\mathrm{b}} \underline{\mathrm{http}: / / w w w . p e r f o r m a n c e . d o h . g o v . u k / w a i t i n g t i m e s / i n d e x . h t m ~}$

chttp://www.cqc.org.uk/usingcareservices/healthcare/nhsstaffsurveys.cfm

dhttp://www.cqc.org.uk/_db/_documents/0607_annual_health_check_performance_rating_scoring_rules_200702284632.pdf

\begin{tabular}{|c|c|c|}
\hline Variable & Notes & Source \\
\hline Foundation Trust Status & & Monitor (Foundation Trust Regulator) \\
\hline Building Age & $\begin{array}{l}\text { Data is provided at the site level and } \\
\text { aggregated up to hospital level using the } \\
\text { surface area as weights }\end{array}$ & $\begin{array}{l}\text { Hospital Estates and Facilities Statistics }{ }^{\mathrm{a}} \text {, The NHS Information Centre for health } \\
\text { and social care. }\end{array}$ \\
\hline Expenditure per patient & $\begin{array}{l}\text { - Cost divided by the number of total } \\
\text { admissions }\end{array}$ & $\begin{array}{l}\text { Cost data from Trusts' Annual Reports and Accounts, available from Trusts' } \\
\text { webpages or Monitor (in the case of Foundation Trusts) }\end{array}$ \\
\hline \multicolumn{3}{|c|}{ a http://www.hefs.ic.nhs.uk/ReportFilter.asp } \\
\hline
\end{tabular}




\section{Table B2: Tests of sample Selection for public hospitals}

\begin{tabular}{lc}
\hline \hline Variable & Marginal effect(Standard error) \\
Performance Measures & \\
Mortality rate from emergency AMI after 28 days (quarterly average) & $0.129(0.161)$ \\
Mortality rate from emergency surgery after 30 days (quarterly average) & $0.313(0.365)$ \\
Numbers on waiting list & $0.025(0.0454)$ \\
Infection rate of MRSA per 10,000 bed days (half yearly) & $-0.025(0.041)$ \\
Operating margin (percent) & $0.040(0.032)$ \\
Likelihood of leaving in next 12 months (1=very unlikely, 5=very likely) & $-0.063(0.04)$ \\
Average Health Care Commission rating (1-4 scale) & $-0.011(0.043)$ \\
Pseudo HCC rating (standardized) & $0.027(0.038)$ \\
Size Variables & \\
Number of total admissions (per 100,000 population) & $0.213(0.417)$ \\
Number of emergency AMI admissions (per 100,000 population) & $53.896(70.863)$ \\
Number of emergency surgery admissions (per 100,000 population) & $0.612(4.739)$ \\
Number of sites & $0.016(0.196)$ \\
Covariates & \\
Foundation Trust (hospitals with greater autonomy) & 163 \\
Building age & $0.091(0.082)$ \\
Expenditure per patient (£ 1000) & $-0.013(0.013)$ \\
Area mortality (average of local authorities in 30km radius, & $-0.015(0.008)^{*}$ \\
$\quad$ per 100,000,000 population) & $0.275(0.277)$ \\
\hline \hline
\end{tabular}

Notes: These are the results from separate probit ML regression of whether a public hospital had any response to the survey on the relevant variable (e.g. AMI mortality rate in the first row). There is a population of 164 potential acute hospitals in England and we had 100 hospitals with at least one respondent. For the first 2 rows we use the same restrictions as in table 2: we use only hospitals with more than 150 yearly cases in the AMI regression and exclude specialist hospitals from the regression in the second row. $* * *$ indicates significance at $1 \%$ level; ** significance at $5 \%$, * for significance at $10 \%$. 


\section{Table B3: Full Results for Baseline Regressions}

\begin{tabular}{|c|c|c|c|c|}
\hline Type of Regression & $\begin{array}{l}(1) \\
\text { OLS }\end{array}$ & $\begin{array}{c}\text { (2) } \\
\text { Reduced } \\
\text { form }\end{array}$ & $\begin{array}{c}(3) \\
1^{\text {st }} \text { Stage }\end{array}$ & $\begin{array}{l}(4) \\
\text { IV }\end{array}$ \\
\hline \multirow[t]{2}{*}{ Dependent Variable } & \multicolumn{4}{|c|}{ ManagementManagement Number Managemen } \\
\hline & score & score & Hospitals & score \\
\hline Number of Competing & $0.120 *$ & & & $0.543^{* *}$ \\
\hline Hospitals & $(0.068)$ & & & $(0.220)$ \\
\hline Proportion of Labour Marginal & & $2.800^{* *}$ & $5.156 * * *$ & \\
\hline Constituencies & & $(1.162)$ & $(1.398)$ & \\
\hline \multicolumn{5}{|l|}{ General Controls } \\
\hline \multirow[t]{2}{*}{ Number of Constituencies } & 0.038 & 0.074 & $0.152 * *$ & -0.008 \\
\hline & $(0.051)$ & $(0.052)$ & $(0.066)$ & $(0.062)$ \\
\hline \multirow[t]{2}{*}{ Labour Share of Votes } & -0.017 & -0.018 & 0.013 & -0.025 \\
\hline & $(0.019)$ & $(0.018)$ & $(0.033)$ & $(0.025)$ \\
\hline Catchment Area Overall Mortality & 0.002 & 0.002 & -0.008 & 0.007 \\
\hline Rate & $(0.004)$ & $(0.003)$ & $(0.005)$ & $(0.005)$ \\
\hline \multirow[t]{2}{*}{ Foundation Trust Dummy } & $0.707 * * *$ & $0.802 * * *$ & 0.237 & $0.673 * * *$ \\
\hline & $(0.169)$ & $(0.161)$ & $(0.314)$ & $(0.234)$ \\
\hline Proportion of Managers with & 0.628 & 0.540 & -0.501 & $0.813^{*}$ \\
\hline Clinical Degree & $(0.384)$ & $(0.370)$ & $(0.353)$ & $(0.435)$ \\
\hline Dummy Clinicians and Managers & $0.275^{*}$ & $0.290 *$ & -0.214 & $0.407^{* *}$ \\
\hline Take Decision Jointly & $(0.141)$ & $(0.148)$ & $(0.207)$ & $(0.175)$ \\
\hline \multicolumn{5}{|l|}{ Interview (Noise) Controls } \\
\hline \multirow[t]{2}{*}{ Clinician Dummy } & $-0.680 * * *$ & $-0.636 * * *$ & -0.134 & $-0.563 * * *$ \\
\hline & $(0.166)$ & $(0.158)$ & $(0.166)$ & $(0.184)$ \\
\hline \multirow[t]{2}{*}{ Interviewer Dummy 1} & 0.239 & 0.341 & 0.433 & 0.105 \\
\hline & $(0.654)$ & $(0.610)$ & $(0.348)$ & $(0.641)$ \\
\hline \multirow[t]{2}{*}{ Interviewer Dummy 2} & -0.491 & -0.401 & 0.404 & -0.620 \\
\hline & $(0.632)$ & $(0.588)$ & $(0.330)$ & $(0.613)$ \\
\hline \multirow[t]{2}{*}{ Interviewer Dummy 3} & 0.249 & 0.492 & 0.534 & 0.201 \\
\hline & $(0.631)$ & $(0.588)$ & $(0.347)$ & $(0.610)$ \\
\hline \multirow[t]{2}{*}{ Tenure in the Post } & $-0.064 * * *$ & $-0.066^{* * *}$ & -0.008 & $-0.061 * * *$ \\
\hline & $(0.018)$ & $(0.017)$ & $(0.023)$ & $(0.022)$ \\
\hline \multicolumn{5}{|l|}{ Population Controls } \\
\hline \multirow{2}{*}{$\begin{array}{l}\text { Total Population in Catchment Area } \\
\text { (unit: } 1,000,000 \text { ) }\end{array}$} & -0.529 & -0.525 & $1.298^{*}$ & -1.230 \\
\hline & $(0.535)$ & $(0.538)$ & $(0.718)$ & $(0.826)$ \\
\hline \multirow{2}{*}{\multicolumn{5}{|c|}{$\begin{array}{l}\text { Age-/ Gender-Controls } \\
\text { (F-stat for } 11 \text { Variables) }\end{array}$}} \\
\hline & & & & \\
\hline \multicolumn{5}{|l|}{ Case-Mix Controls } \\
\hline Total Admissions & $0.339 * * *$ & $0.415^{* * *}$ & 0.201 & $0.306 * * *$ \\
\hline (unit: 10,000) & $(0.103)$ & $(0.108)$ & $(0.146)$ & $(0.112)$ \\
\hline $\begin{array}{l}\text { Age-/ Gender Controls } \\
\text { (F-stat for } 21 \text { Variables) }\end{array}$ & $4.00 * * *$ & $2.39 * * *$ & $2.10 * * *$ & $2.81^{* * *}$ \\
\hline Observations & 161 & 161 & 161 & 161 \\
\hline
\end{tabular}

Notes: *** indicates significance at the $1 \%$ level; ${ }^{* *}$ significance at $5 \%, *$ significance at $10 \%$. Competition is measured as the number of hospitals in a $30 \mathrm{~km}$ radius around the hospital (the "catchment area"). A Political Constituency is defined as marginal if it was won by less than $5 \%$ in the 1997 UK General Election and the proportion of marginal constituencies is based on the $30 \mathrm{~km}$ catchment area. The Labour share of votes is the absolute share obtained by the Labour party in the 1997 UK General Election averaged over all constituencies in the catchment area. Standard errors are clustered at a hospital level (the unit of observations is a service line in cardiology or orthopaedics). All variables in the regressions are reported in the table. The observations are weighted by the inverse of the number of interviews within the same hospital. 
Figure A1: Correlation in management scores between independent first and second interviews on different managers or doctors in the same hospital

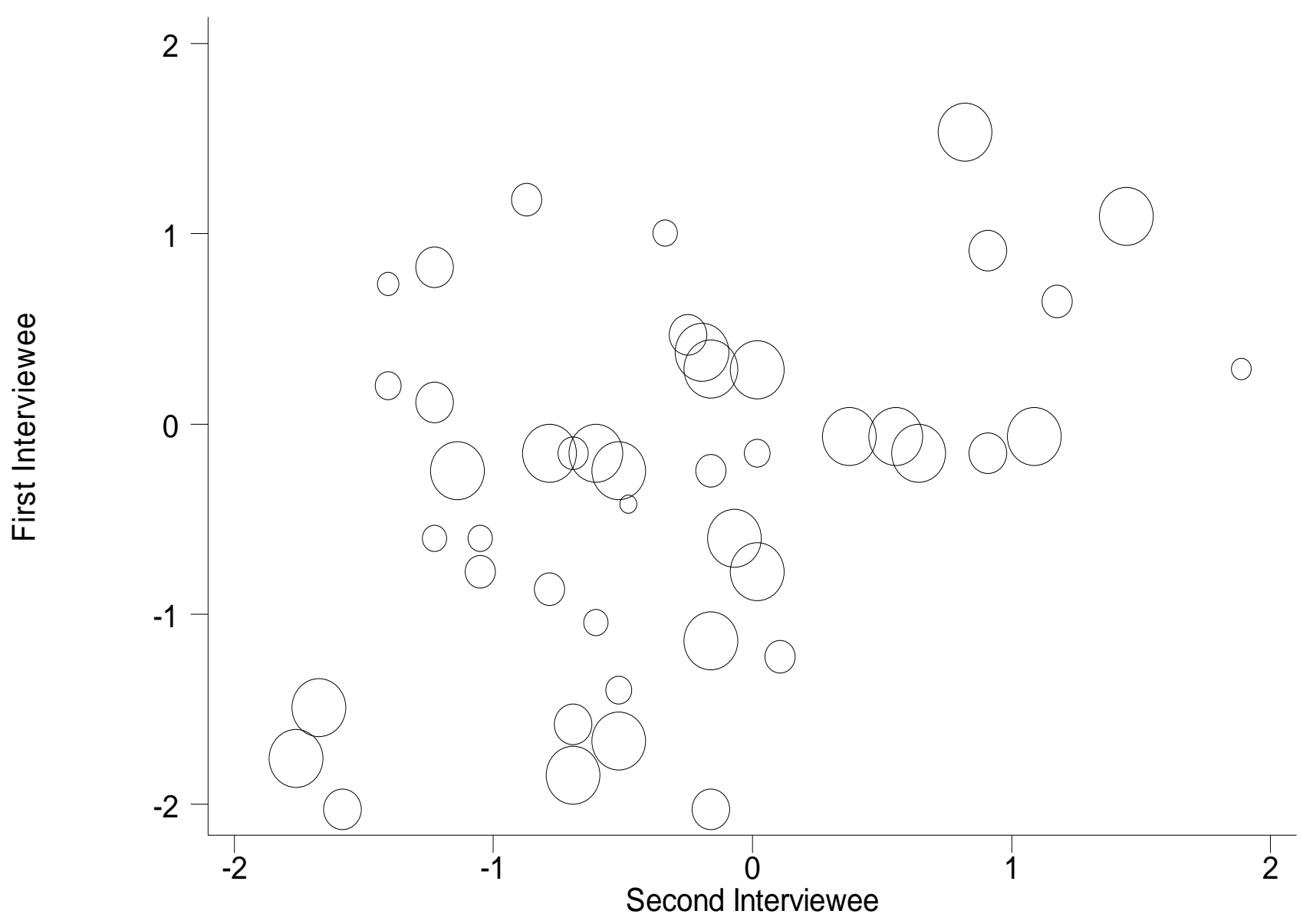

Notes: Plots the standardized management scores for hospitals where two (or more) independently run interviews have taken place on different managers and/or doctors in different departments. Weight is the inverse of the number of different hospital sites (correlation is 0.53 ). 